\title{
Systematic review of international guidelines for head and neck oncology management in COVID-19 patients
}

\author{
Laurence Gascon $^{1,2} \cdot$ Isabelle Fournier ${ }^{1,2}$. Carlos Chiesa-Estomba ${ }^{1,3} \cdot$ Gennaro Russo $^{1,4}$ • Nicolas Fakhry ${ }^{1,5}$. \\ Jérôme R. Lechien ${ }^{1,6} \cdot$ Lisa Burnell ${ }^{1,7}$. Sebastien Vergez ${ }^{1,8}$. Osama Metwaly ${ }^{1,9}$. Pasquale Capasso ${ }^{1,4}$. \\ Tareck Ayad ${ }^{1,2}$ (1)
}

Received: 19 August 2020 / Accepted: 11 April 2021 / Published online: 23 April 2021

(c) The Author(s), under exclusive licence to Springer-Verlag GmbH Germany, part of Springer Nature 2021

\begin{abstract}
Purpose The coronavirus pandemic has redefined the practice of head and neck surgeons in the management of oncology patients. Several countries have issued practice recommendations in that context. This review is a collaboration of the YOIFOS (Young Otolaryngologists of the International Federation of Otolaryngological Societies) group in order to summarize, in a systematic way, all available guidelines and provide clear guidelines for the management of head and neck cancer patients in the COVID-19 pandemic.

Methods This systematic review was performed according to the PRISMA statements. Inclusion criteria for the systematic review were based on the population, intervention, comparison, and outcomes according to (PICO) framework. The AGREE II (Appraisal of Guidelines for Research and Evaluation II) instrument was used to assess quality of all practice guidelines included in this review.

Results Recommendations include adjustments regarding new patients' referral such as performing a pre-appointment triage and working in telemedicine when possible. Surgical prioritization must be adjusted in order to respect pandemic requirements. High-grade malignancies should, howeve,r not be delayed, due to potential serious consequences. Many head and neck interventions being aerosol-generating procedures, COVID-19 testing prior to a surgery and adequate PPE precautions are essential in operating rooms.
\end{abstract}

Conclusion These recommendations for head and neck oncology patients serve as a guide for physicians in the pandemic. Adjustments and updates are necessary as the pandemic evolves.

Keywords COVID-19 $\cdot$ Coronavirus $\cdot$ Head and neck cancer $\cdot$ Oncology $\cdot$ Guidelines

Laurence Gascon and Isabelle Fournier have equally contributed to this work and should be regarded as joint first authors.

Tareck Ayad

tareck.ayad@umontreal.ca

1 Task Force COVID-19 of the Young-Otolaryngologists of the International Federations of Oto-rhino-laryngological Societies (YO-IFOS), Paris, France

2 Division of Otolaryngology-Head and Neck Surgery, Centre Hospitalier de l'Université de Montréal, 1051, rue Sanguinet, Montréal, QC H2X 0C1, Canada

3 Department of Otorhinolaryngology-Head and Neck Surgery, Hospital Universitario Donostia, San Sebastián, Spain

4 Otolaryngology Head and Neck Surgery Unit of "Azienda Ospedaliera di Rilievo Nazionale dei Colli, Ospedale Monaldi", Naples, Italy
5 Otolaryngology-Head and Neck Surgery Department, University Hospital of la Conception, APHM, Aix-Marseille Univ, Marseille, France

6 Department of Otolaryngology-Head and Neck Surgery, School of Medicine, Foch Hospital, UFR Simone Veil, Université Versailles Saint-Quentin-en-Yvelines (Paris Saclay University), Paris, France

7 ENT Morningside, Morningside Mediclinic Sandton, Johannesburg, South Africa

8 Head and Neck Surgery Department, University Cancer Institute of Toulouse-Oncopole, Toulouse University Hospital, Toulouse, France

9 Kasr Alainy School of Medicine, Cairo University, Cairo, Egypt 


\section{Introduction}

The coronavirus pandemic has forced Otorhinolaryngologists Head and Neck Surgeons (ORL-HNS) to redefine their practice. First, ORL-HNS are faced with an increased risk to be exposed to COVID-19 due to high viral loads in the upper respiratory tract [1]. Second, several hospitals have significantly reduced planned surgeries to avoid overwhelming the healthcare system and to conserve critical resources. However, ORL-HNS have an obligation to ensure that each of their patients can benefit from the most appropriate treatment possible, despite the pandemic. This is even more true for oncologic patients, where the choice of treatment plan can have a direct impact on the patient's survival outcome and quality of life. To guide ORL-HNS navigate in health systems with limited services and to minimize the patients and otolaryngology team's exposure to the severe acute respiratory syndrome coronavirus-2 (SARS-CoV-2), several countries have issued practice recommendations regarding oncologic patients. The objective of this study is to systematic review all available guidelines and assess their quality.

As an initiative of the "Young Otolaryngologist Group of the International Federation of Otolaryngologic Societies" (YO-IFOS), this review aims to summarize in a systematic way the available recommendations for management of $\mathrm{H} \& \mathrm{~N}$ cancer in the COVID-19 pandemic era and assess the quality of available guidelines. These recommendations are mostly oriented for otolaryngologists but could be useful for any physician treating and following head and neck oncology patients.

\section{Materials and methods}

This systematic and qualitative review was performed according to the PRISMA template for systematic reviews and meta-analyses [2,3]. The following clinical databases were consulted to collect information: PUBMED, Google Scholar, Ovid Medline and Scopus. International ORLHNS societies, and association websites were reviewed to find guidelines and recommendation documents regarding the COVID-19 pandemic. Search terms included "SARSCoV-2", "COVID-19", "guidelines/practice guidelines/clinical guidelines," "recommendations" "consensus," "ENT," "head and Neck surgery", "oncology surgery", "head and neck cancer". Researches were also performed on all the international societies and associations' websites in order to obtain their guidelines and recommendations if available. Research was conducted from January 2020 to May 2020.

Two reviewers (L.G. and I.F.) examined available guidelines and only included those that were relevant to oncology surgery. They both independently performed title and abstract screening and full text reviews. Citations that did not meet the inclusion criteria were discarded. The most recent version or update of each clinical guideline was included and analyzed. Reviewers resolved disagreements through discussion.

Inclusion criteria for the systematic review were based on the population, intervention, comparison, and outcomes according to (PICO) framework [4].

\section{Populations}

Inclusion criteria consisted of COVID-19 guidelines for otolaryngologist and head and neck surgeons, for head and neck oncology treatment strategies and for oncology surgeries. Guidelines in French, English, Spanish and Portuguese were included.

\section{Intervention and comparison}

Reviewed guidelines and recommendation documents were analyzed and compared, specifically for medical care of head and neck oncology patients. New referrals, investigations, surgery prioritization, personal protection equipment (PPE), COVID testing for surgeries, surgical techniques, team management and postoperative care were compared in each guideline.

\section{Outcome}

The outcome of interest was to provide a set of recommendations based on current evidence, in order to guide otolaryngologists with care of patients suffering from head and neck cancer in the COVID-19 context.

The AGREE II (Appraisal of Guidelines for Research and Evaluation II) instrument was used to assess quality of all practice guidelines included in this review [4]. The evaluation was performed independently by two appraisers (L.G. and I.F.). To measure interobserver agreement across the ordinal categories of the AGREE-II ratings, a weighted kappa was calculated. Degrees of agreement were graded as minor $(\leq 0.20)$, fair $(0.21-0.40)$, moderate $(0.41-0.60)$, substantial (0.61-0.80) and almost perfect $(\geq 0.81)$.

The ethics committee approval was not required for the study.

\section{Results}

A total of 23 guidelines were included in this systematic review (Table 1). The guidelines came from the following world regions: North America (2 from Canada [5, 6] and 6 from USA [7-13]), South America (1 from Argentina 
Table 1 Guidelines included in this systematic review

\begin{tabular}{|c|c|c|c|}
\hline & Country & Guideline & Last update \\
\hline 1 & Canada & $\begin{array}{l}\text { Guidelines for management of Head and Neck Cancer during the COVID-19 } \\
\text { pandemic }\end{array}$ & March 30, 2020 \\
\hline 2 & Canada (Quebec) & $\begin{array}{l}\text { Recommandations pour la priorisation des patients en contexte de pandémie } \\
\text { de COVID-19 - Volet Cancers ORL / tête et cou }\end{array}$ & April 15, 2020 \\
\hline 3 & United States of America (USA) & COVID 19: Elective Case Triage Guidelines for Surgical Care & March 24, 2020 \\
\hline 4 & United States of America (USA) & Endocrine surgery in the Coronavirus disease 2019 pandemic & April 16, 2020 \\
\hline 5 & United States of America (USA) & $\begin{array}{l}\text { Safety Recommendations for Evaluation and Surgery of the Head and Neck } \\
\text { During the COVID-19 Pandemic }\end{array}$ & March 31, 2020 \\
\hline 6 & United States of America (USA) & COVID-19 and the Otolaryngologist: Preliminary Evidence-Based Review & March 26, 2020 \\
\hline 7 & United States of America (USA) & HN Cancer Care Guidelines during COVID-19 Epidemic & March 22, 2020 \\
\hline 8 & United States of America (USA) & Guidance for return to practice for Otolaryngology-Head and neck surgery & May 5,2020 \\
\hline 9 & Argentina & $\begin{array}{l}\text { Protocolo interno COVID-19 para consultas y prácticas del servicio de Otor- } \\
\text { rinolaringología }\end{array}$ & April 17, 2020 \\
\hline 10 & Chile & $\begin{array}{l}\text { Recomendaciones de la socieded chilena de otorrinilaringologia, medicina } \\
\text { y cirugia de Cabeza y cuello para el ejercicio de la especialidad durante } \\
\text { pandemia COVID-19 (SARS-CoV-2) }\end{array}$ & March 22, 2020 \\
\hline 11 & Brazil & $\begin{array}{l}\text { Recomendação da SBCCP sobre atendimento médico na; Especialidade } \\
\text { durante epidemia de COVID-19 }\end{array}$ & March 23, 2020 \\
\hline 12 & United Kingdom & $\begin{array}{l}\text { Initial guidance for head and neck cancer management during COVID-19 } \\
\text { pandemic in consultation with ENT UK }\end{array}$ & March 27, 2020 \\
\hline 13 & United Kingdom & BAETS statement on COVID-19 and Thyroid Cancer Services & March, 2020 \\
\hline 14 & Ireland & Considerations on H\&N during COVID-19 & March 20, 2020 \\
\hline 15 & France & $\begin{array}{l}\text { French consensus on management of head and neck cancer surgery during } \\
\text { COVID-19 pandemic }\end{array}$ & April 11, 2020 \\
\hline 16 & Spain & $\begin{array}{l}\text { Estrategias para el manejo del paciente orl durante la fase de control de la } \\
\text { pandemia por la COVID-19 }\end{array}$ & April 20, 2020 \\
\hline 17 & Spain & Recomendaciones secomcyc en relacion con la cirugia y COVID-19 & $\mathrm{NE}$ \\
\hline 18 & Thailand & $\begin{array}{l}\text { Statement from The Royal College of Otolaryngologists-Head and Neck } \\
\text { Surgeons of Thailand }\end{array}$ & $\mathrm{NE}$ \\
\hline 19 & South Africa & COVID-19 Recommendations for the ENT Surgeon & $\mathrm{NE}$ \\
\hline 20 & Australia & $\begin{array}{l}\text { ASOHNS Review of Guidance for PPE for ENT surgeons during the COVID- } \\
19 \text { Pandemic }\end{array}$ & April 2, 2020 \\
\hline 21 & Australia & $\begin{array}{l}\text { Recommendations for PPE for Aerosol Generating Procedures during } \\
\text { COVID-19 pandemic }\end{array}$ & March 24, 2020 \\
\hline 22 & Australasian (Australia and New Zealand) & $\begin{array}{l}\text { RACS guidelines for the management of surgical patients during the COVID- } \\
19 \text { pandemic }\end{array}$ & $\mathrm{NE}$ \\
\hline 23 & Italy & $\begin{array}{l}\text { Piano strategico per la gestione del paziente orl durante il periodo di tran- } \\
\text { sizione a seguito della pandemia per il COVID-19-versione } 2\end{array}$ & $\mathrm{NE}$ \\
\hline
\end{tabular}

$N E$ non specified

[14], 1 from Chile [15] and 1 from Brazil [16]), Europe (2 from United Kingdom [17, 18], 1 from Ireland [19], 1 from France [20], 2 from Spain [21, 22] and 1 from Italy [23]), Asia (from Thailand [24]), Africa (from South Africa [25]) and Oceania (2 from Australia [26, 27] and 1 from the Australasian association [28]).

Data from these guidelines were examined and compared according to the different categories, as presented in Annex 1 (Table 4).

\section{Appraisal of guidelines}

The AGREE domain scores are shown in Table 2.

\section{Scope and purpose}

Overall, the objectives and purpose of the guidelines were very well defined amongst the guidelines. In this domain, 13 guidelines had a perfect score of $100[6,8-10,13-15$, $17,19-21,23], 8$ guidelines had a score $>80[5,7,12$, $24-26,26,28]$ and 2 guidelines had a score under 70 [16, $22]$. The mean score for this section was 90.8 . 
Table 2 Guideline assessment according to the AGREE-II Instrument

\begin{tabular}{|c|c|c|c|c|c|c|c|c|}
\hline $\begin{array}{l}\text { Guideline organization } \\
\text { or society }\end{array}$ & $\begin{array}{l}\text { Scope } \\
\text { and pur- } \\
\text { pose }\end{array}$ & $\begin{array}{l}\text { Stakeholder } \\
\text { involvement }\end{array}$ & $\begin{array}{l}\text { Rigour and } \\
\text { development }\end{array}$ & $\begin{array}{l}\text { Clarity and } \\
\text { presentation }\end{array}$ & Applicability & $\begin{array}{l}\text { Editorial } \\
\text { independ- } \\
\text { ence }\end{array}$ & $\begin{array}{l}\text { Mean } \\
\text { domain } \\
\text { scores }(\%)\end{array}$ & $\begin{array}{l}\text { Agreement between } \\
\text { appraisers (Cohen's } \\
\text { Kappa) }\end{array}$ \\
\hline $\begin{array}{l}\text { Canadian Association } \\
\text { of Head and Neck } \\
\text { Surgical Oncol- } \\
\text { ogy (CAHNSO) } \\
\text { guidelines }\end{array}$ & 91.7 & 77.8 & 56.3 & 72.2 & 100 & 50 & 74.7 & 0.93 \\
\hline $\begin{array}{l}\text { Initial guidance for } \\
\text { head and neck } \\
\text { cancer management } \\
\text { during COVID-19 } \\
\text { pandemic in consulta- } \\
\text { tion with ENT UK }\end{array}$ & 91.7 & 72.2 & 50.0 & 100 & 93.8 & 50.0 & 76.3 & 0.79 \\
\hline $\begin{array}{l}\text { Recommandations } \\
\text { pour la priorisa- } \\
\text { tion des patients en } \\
\text { contexte de } \\
\text { pandémie de COVID- } \\
\text { 19-Volet Cancers } \\
\text { ORL/tête et cou }\end{array}$ & 100 & 100 & 70.8 & 94.4 & 95.8 & 0 & 76.9 & 0.91 \\
\hline $\begin{array}{l}\text { BAETS-British asso- } \\
\text { ciation of endocrine } \\
\text { and thyroid surgeons }\end{array}$ & 100 & 86.1 & 54.2 & 94.4 & 95.8 & 0 & 71.8 & 0.73 \\
\hline $\begin{array}{l}\text { American College of } \\
\text { Surgery-COVID } \\
\text { 19: Electives case } \\
\text { triage guidelines for } \\
\text { surgical care }\end{array}$ & 83.3 & 61.1 & 51.0 & 86.1 & 83.3 & 4.2 & 61.5 & 0.71 \\
\hline $\begin{array}{l}\text { Protocolo interno } \\
\text { COVID-19 para } \\
\text { consultas y prácticas } \\
\text { del servicio de Otor- } \\
\text { rinolaringología }\end{array}$ & 100 & 100 & 59.4 & 100 & 83.3 & 0 & 73.8 & 0.92 \\
\hline $\begin{array}{l}\text { French consensus on } \\
\text { management of head } \\
\text { and neck cancer sur- } \\
\text { gery during COVID- } \\
19 \text { pandemic }\end{array}$ & 100 & 100 & 44.8 & 77.8 & 95.8 & 100 & 86.4 & 0.76 \\
\hline $\begin{array}{l}\text { Statement from The } \\
\text { Royal College of } \\
\text { Otolaryngologists- } \\
\text { Head and Neck Sur- } \\
\text { geons of Thailand }\end{array}$ & 80.6 & 44.4 & 21.9 & 80.6 & 60.4 & 0 & 48.0 & 0.61 \\
\hline $\begin{array}{l}\text { Royal Australasian } \\
\text { College of Surgeons } \\
\text { guidelines for the } \\
\text { management of } \\
\text { surgical patients dur- } \\
\text { ing the COVID-19 } \\
\text { pandemic }\end{array}$ & 94.4 & 61.1 & 45.8 & 100 & 62.5 & 0 & 60.6 & 0.77 \\
\hline $\begin{array}{l}\text { ASOHNS_-Review } \\
\text { of Guidance for PPE } \\
\text { for ENT surgeons } \\
\text { during the COVID- } \\
19 \text { Pandemic }\end{array}$ & 83.3 & 72.2 & 61.5 & 94.4 & 70.8 & 0 & 63.7 & 0.39 \\
\hline
\end{tabular}


Table 2 (continued)

\begin{tabular}{|c|c|c|c|c|c|c|c|c|}
\hline $\begin{array}{l}\text { Guideline organization } \\
\text { or society }\end{array}$ & $\begin{array}{l}\text { Scope } \\
\text { and pur- } \\
\text { pose }\end{array}$ & $\begin{array}{l}\text { Stakeholder } \\
\text { involvement }\end{array}$ & $\begin{array}{l}\text { Rigour and } \\
\text { development }\end{array}$ & $\begin{array}{l}\text { Clarity and } \\
\text { presentation }\end{array}$ & Applicability & $\begin{array}{l}\text { Editorial } \\
\text { independ- } \\
\text { ence }\end{array}$ & $\begin{array}{l}\text { Mean } \\
\text { domain } \\
\text { scores }(\%)\end{array}$ & $\begin{array}{l}\text { Agreement between } \\
\text { appraisers (Cohen's } \\
\text { Kappa) }\end{array}$ \\
\hline $\begin{array}{l}\text { Western Australian } \\
\text { ENT Recommenda- } \\
\text { tions for PPE for } \\
\text { Aerosol Generating } \\
\text { Procedures during } \\
\text { COVID-19 Pan- } \\
\text { demic }\end{array}$ & 88.9 & 75 & 53.1 & 100 & 77.1 & 0 & 65.7 & 0.74 \\
\hline $\begin{array}{l}\text { Recommendations } \\
\text { compiled by the } \\
\text { University of Cape } \\
\text { Town Division of } \\
\text { Otolaryngology }\end{array}$ & 88.9 & 58.3 & 50 & 100 & 70.8 & 0 & 61.3 & 0.82 \\
\hline $\begin{array}{l}\text { Sociedad Chilena } \\
\text { de Otorrinolaring- } \\
\text { gologia }\end{array}$ & 100 & 52.8 & 52.1 & 94.4 & 64.6 & 0 & 60.6 & 0.65 \\
\hline $\begin{array}{l}\text { Sociedad Espanola de } \\
\text { Otorrinolaringologia } \\
\text { y Cirurgia de Cabeza } \\
\text { y Cuello }\end{array}$ & 100 & 72.2 & 56.3 & 100 & 79.2 & 16.7 & 70.7 & 0.78 \\
\hline $\begin{array}{l}\text { Recomendaciones } \\
\text { secomcyc en rela- } \\
\text { cion con la cirugia y } \\
\text { COVID-19 }\end{array}$ & 16.7 & 16.7 & 24.0 & 88.9 & 56.3 & 0 & 33.7 & 0.71 \\
\hline $\begin{array}{l}\text { Endocrine Surgery in } \\
\text { the Coronavirus Dis- } \\
\text { ease } 2019 \text { Pandemic }\end{array}$ & 100 & 66.7 & 66.7 & 100 & 66.7 & 75 & 79.2 & 0.63 \\
\hline $\begin{array}{l}\text { Irish Head and Neck } \\
\text { Society Considera- } \\
\text { tions on H\&N dur- } \\
\text { ing COVID-19 }\end{array}$ & 100 & 47.2 & 57.3 & 100 & 75 & 0 & 63.3 & 0.77 \\
\hline $\begin{array}{l}\text { JAMA Otolaryngol- } \\
\text { ogy-Head and Neck } \\
\text { Surgery: Safety } \\
\text { Recommendations } \\
\text { for Evaluation and } \\
\text { Surgery } \\
\text { of the Head and Neck } \\
\text { During the COVID- } \\
19 \text { Pandemic }\end{array}$ & 100 & 88.9 & 74.0 & 94.4 & 70.8 & 100 & 88.0 & 0.57 \\
\hline $\begin{array}{l}\text { The American Laryn- } \\
\text { gological, } \\
\text { Rhinological and } \\
\text { Otological Society, } \\
\text { Inc. COVID-19 and } \\
\text { the Otolaryngolo- } \\
\text { gist: Preliminary } \\
\text { Evidence-Based } \\
\text { Review }\end{array}$ & 100 & 77.8 & 60.4 & 100 & 75 & 100 & 85.5 & 0.75 \\
\hline $\begin{array}{l}\text { HN Cancer Care } \\
\text { Guidelines dur- } \\
\text { ing COVID-19 } \\
\text { Epidemic: Northern } \\
\text { California }\end{array}$ & 100 & 83.3 & 35.4 & 100 & 87.5 & 0 & 67.7 & 0.53 \\
\hline
\end{tabular}


Table 2 (continued)

\begin{tabular}{|c|c|c|c|c|c|c|c|c|}
\hline $\begin{array}{l}\text { Guideline organization } \\
\text { or society }\end{array}$ & $\begin{array}{l}\text { Scope } \\
\text { and pur- } \\
\text { pose }\end{array}$ & $\begin{array}{l}\text { Stakeholder } \\
\text { involvement }\end{array}$ & $\begin{array}{l}\text { Rigour and } \\
\text { development }\end{array}$ & $\begin{array}{l}\text { Clarity and } \\
\text { presentation }\end{array}$ & Applicability & $\begin{array}{l}\text { Editorial } \\
\text { independ- } \\
\text { ence }\end{array}$ & $\begin{array}{l}\text { Mean } \\
\text { domain } \\
\text { scores }(\%)\end{array}$ & $\begin{array}{l}\text { Agreement between } \\
\text { appraisers (Cohen's } \\
\text { Kappa) }\end{array}$ \\
\hline $\begin{array}{l}\text { American academy } \\
\text { of otolaryngology- } \\
\text { head and neck sur- } \\
\text { gery: Guidance for } \\
\text { Return to Practice } \\
\text { for Otolaryngology- } \\
\text { Head and Neck } \\
\text { Surgery }\end{array}$ & 100 & 55.6 & 56.3 & 100 & 68.8 & 0 & 63.4 & 0.68 \\
\hline $\begin{array}{l}\text { Recomendação da } \\
\text { SBCCP sobre } \\
\text { atendimento médico } \\
\text { na; Especialidade } \\
\text { durante epidemia de } \\
\text { COVID-19 }\end{array}$ & 69.4 & 61.1 & 42.7 & 63.9 & 75 & 75 & 64.5 & 0.63 \\
\hline $\begin{array}{l}\text { Piano strategico per la } \\
\text { gestione del paziente } \\
\text { orl durante il peri- } \\
\text { odo di transizione } \\
\text { a seguito della } \\
\text { pandemia per il } \\
\text { COVID-19 }\end{array}$ & 100 & 83.3 & 55.2 & 75 & 72,9 & 50 & 72,7 & 0.69 \\
\hline Mean & 90.4 & 66.5 & 52.1 & 92.0 & 77.4 & 27.0 & 67.7 & 0.72 \\
\hline Standard deviation & 18.2 & 24.4 & 12.6 & 10.8 & 12.5 & 38.3 & 12.3 & 0.12 \\
\hline
\end{tabular}

\section{Stakeholder involvement}

This domain ensures that the guidelines report the names of the people involved in the redaction of the document. Most of the guidelines reported a complete list of the author's names or reported at least the society responsible for the document. The target population was commonly clearly identified in the references. However, the view and preferences of the target population is a point that was not frequently reported, which can explain the lower scores in this sub-section. The mean score for this section was 70.2 with 7 guidelines scoring $>80[6,8,11,14,18,20,23]$.

\section{Rigour of development}

The results of the different sections in this domain were very mixed. The mean score was 52.1 with two guidelines scoring $>70[6,9]$. A minority of the guidelines reported the search method or inclusion criteria for the design of their documents and none of them reported the methods used to formulate recommendations. This can be explained by the urgency of the context in which the guidelines were published. However, strengths and limitations of the guidelines, the consideration of benefit and harm as well as the selected strategy to update the documents were generally well cited.

\section{Clarity and presentation}

The majority of the guidelines presented clear recommendations that were easy to identify and demonstrated management options. Few offered checklists and algorithms. In fact, this domain had the highest mean score of 92.0 with 11 guidelines having a perfect 100 score $[8,10,11,13,14$, $17,19,21,24,25,27]$.

\section{Applicability}

Applicability was well reported in the guidelines, especially regarding specific facilitators and barriers, which took the COVID context in consideration. Monitoring and auditing criteria were often lacking in the guidelines. The overall score was good, with a mean of 77.4 and with 8 guidelines with a score $>80[5-7,11,14,17,18,20]$.

\section{Editorial independence}

Funding body and conflicts of interests were either well reported or absent. Only a minority of guidelines cited conflicts of interest. However, this domain is not as relevant in the pandemic context as most of the guidelines were produced by international societies. 


\section{Overall assessment}

Twenty [5, 6, 8-11, 13-21, 23, 25-28] out of the 23 guidelines showed an overall appreciation score of 6 and above and all the guidelines were assessed as recommended for the care of patients with head and neck cancer in the COVID-19 context.

The mean scores (range; SD) for the domains were the following: scope and purpose $90.8 \%$ (16.7-100\%; SD 18.2); stakeholder involvement $70.2 \%$ (16.7-100\%; SD 19.9); rigour of development $52.1 \%$ (21.9-74.0\%; SD 12.6); clarity of presentation $92.0 \%$ (63.9-100\%; SD 10.8); applicability $77.4 \%$ (56.3-100\%; SD 12.5) and editorial independence $26.9 \%$ (0-100\%; SD 38.3). The kappa values ranged from 0.39 to very good 0.93 . The overall inter-rater agreement was intraclass correlation $=0.72$, indicating good strength of agreement.

\section{Statements}

The following statements are a consensus of the guidelines and recommendations available regarding the management of head and neck oncology patients in the COVID-19 context. As the pandemic continues and otolaryngologists see a need to redesign their practice, these statements serve as guidance in their daily clinical activities. They are adapted to the gradual resumption of activities in the new context of COVID-19. Reviews, updates and revisions are expected in this exceptional situation.

\section{How to manage new patients and referrals for malig-} nancy suspicions?

As mandated by the COVID-19 context, social contacts must be limited to minimize virus transmission. Therefore, reorganization of the otolaryngology clinics and management of new patients' referrals to head and neck cancer clinics is needed. Guidelines included in this review recommend performing triage, in order to determine which patients require face-to-face visits, telemedicine consultation or appointment deferral. When possible, first consultation for new referrals should be conducted by telephone or videoconference, to assess the need or urgency to evaluate the patient in person. New patients with high suspicion for malignancy require face-to-face consultations [20, 23]. In the current context, referrals for benign and non-cancer diseases should be delayed, but it is recommended that physicians keep track of delayed patients and reevaluate them frequently. In-clinic follow-ups should be scheduled when the COVID-19 situation improves. New referrals for emergent or time-sensitive pathologies should be evaluated in clinic. These include rapidly evolving neck masses or patients with stridor [17]. Regarding follow-up appoint- ments for oncology patients, certain conditions are nondeferrable according to the Society of Otolaryngology in Spain. These include patients with signs or symptoms of recurrent diseases, verification of treatment response and neck infections [21].

Some adjustments are recommended for in-clinic visits. Patients at risk of suffering from complications of COVID-19 should be prioritized to minimize time in hospital when phone consultation is not an option [19]. All patients should have a phone screening for symptoms of COVID-19 and for contact with positive cases prior to visiting. Waiting rooms and hallways should allow a two-meter distance between people to respect social distancing guidelines. Patients should also be advised to come to the clinic alone and to wear a mask at all times [13]. As the COVID-19 context keeps evolving, and facing the high probability of a second wave, measures to limit the number of patients in clinic and contact between people should be maintained. Patient prioritization should, however, take place according to the phases of the crisis [11] with a rigorous schedule to keep track of deferred appointments.

2. What workup and investigations can we go forward with for oncological assessment?

Diagnostic workup and investigations in head and neck oncology patients include imaging, biopsies and repeated examinations, such as flexible laryngoscopy. However, due to the COVID-19 pandemic, the number of patients in the hospital has to be limited. In this context, diagnostic workup for benign pathologies or lowrisk malignancies is recommended to be deferred. Also, in an asymptomatic or stable patient, imaging followup can be postponed to the next follow-up cycle [11]. Patients whose workup is postponed should be advised to watch for new symptoms and to contact the clinic or nurse for any change in their condition. Biopsies and imaging must be limited to patients with a high risk of malignancies or for symptomatic patients. Diagnostic workup must be reduced to a minimum and should be exclusively for treatment decision making. In order to minimize time spent in the hospital, all investigations should be done the same day [6]. If multiple investigations and treatments are required, they should be performed in a single hospital stay [20].

Flexible laryngoscopy is considered to be an aerosol generating procedure [5, 6, 10-22]. Given the high proportion of infected asymptomatic patients, flexible laryngoscopies should be postponed. However, ORLHNS can perform flexible laryngoscopies when it is deemed that it will reduce the patient's morbidity in the next 30 days $[10,14]$. If the flexible laryngoscopy is mandatory for a life-threatening pathology or essential for decision-making, it should be performed in aerosol- 
generating procedure precautions. If the COVID-19 status is negative or unknown in an asymptomatic patient, the examination should be performed by the treating physician with the least amount of people in the room. It is advised to perform flexible laryngoscopy with a video camera and tower and to record the exam to allow another specialist to consult it rather than repeating it. If topical analgesia is necessary, the use of pledgets is recommended over sprays. The personal protective equipment for the procedure should include scrubs, gown, N95 mask, face shield or eye protection and gloves. If the patient is COVID + or presumed positive with symptoms, the procedure should be performed in a negative pressure room with the addition of a surgical hood, double gloves and a powered air purifying respirators (PAPR) if available.

If a biopsy in the mouth is necessary, guidelines from Spain recommended to mouthwash with oxidizing agents such as $1 \%$ hydrogen peroxide or $0.2 \%$ providone iodine to reduce the load of microbes in saliva [22].

Finally, regarding thyroid nodules, an observation strategy can be recommended with follow-up in 6 to 12 months unless the nodule is enlarging or unless it falls in the criteria indicated for biopsy [18]. Workup and investigations should therefore be minimized to what is essential for proper patient management. Also, follow-up should be closely maintained if the investigations are delayed.

3. What are the prioritization recommendations for oncological surgeries?

Surgical planning should take into consideration the impact on patient outcome when delaying surgeries against the inherent risk of contamination from SARSCoV-2 virus when conducting a surgery. In most guidelines included in this review, the waiting time recommended for oncological surgeries is divided into three groups. The first group is for patients requiring emergent surgeries, which typically includes cancers with airway compromise or with hemorrhage $[6,20,26]$. The second group is composed of surgeries which should not be rescheduled for more than 4 to 6 weeks, such as high stage squamous cell cancers of the aerodigestive tract (oral cavity, oropharynx, larynx, hypopharynx and nasopharynx), cancers with impending airway compromise, high grade or progressive salivary gland cancers, T3 or T4 melanoma, skin cancers with regional disease or with progression, thyroid cancers with aerodigestive invasion or with locoregional metastasis or with progression, anaplastic thyroid cancers and recurrent or persistent cancer which requires a salvage surgery $[5,8,11,15,18,20$, $22,23,26,29]$. These are time-sensitive pathologies in whom longer delay can have important consequences on disease progression and comorbidity. The third group is composed of surgeries that can be postponed for more than 6 weeks, such as low-grade squamous cell cancers of the upper aerodigestive tract, low-grade and non-progressive salivary gland cancers, non-progressive and non-metastatic skin cancers, well-differentiated thyroid cancers (papillary and follicular thyroid cancers), medullary thyroid cancers and superficial lesions of the vocal cords [5, 8, 11, 14, 15, 18, 20, 22, 26].

4. How should COVID-19 status be assessed prior to surgery?

It is unanimously recommended by all guidelines providing information on COVID-19 status prior to a surgery, to perform a COVID-19 test using viral polymerase chain reaction reverse transcription (PCR-RT) if time allows it. Non-emergent procedures should not be performed until the result is available. It is recommended to proceed with the surgery if the COVID-19 test is negative. Five societies recommend two negative tests with an interval between them [19, 21, 23, 25, 26]. The rest of the guidelines recommend a single test $24 \mathrm{~h}$ prior to the surgery $[11,20,24]$ or do not specify the number of tests required. Two societies recommend the use of antibody testing if available [23, 25]. Guidelines from France recommend chest CT-scan $24 \mathrm{~h}$ before surgery [20]. The surgery should be postponed at least 14 days if the COVID-19 status comes back positive. If the surgery must take place in an urgent setting and the COVID-19 status is positive or cannot be determined, the surgery should take place in full COVID-19 precautions and in a dedicated operating room. All unknown COVID-19 statuses should be considered as positive. It is recommended to contact patients a few days prior to their surgery to investigate for COVID-19 symptoms and risks factors [20]. After the patient COVID-19 testing, the patient should remain self-isolated until the day of the surgery [13].

5. What personal protection equipment (PPE) should be worn for oncological surgeries of the head and neck?

PPE is essential to minimize exposure of the otolaryngology team to SARS-CoV-2 virus. The otolaryngology team must be familiar with procedures to properly put on and safely dispose PPE [26]. Surgical masks protect against droplets transmission while N95 masks or PAPR protect against aerosol transmission [13]. PAPR offers better protection against aerosols when compared to N95, but is incompatible with the use of a headlamp, microscope, or loupes [7]. Eye protection includes goggles and face shield.

The American Academy of Otolaryngology-Head and Neck Surgery recommends adding the following in the preoperative timeout: patient's COVID-19 testing status, appropriate PPE to use and possible methods of transmission (droplets or aerosols) during surgery [13]. 
The level of PPE required depends on the patient's COVID-19 testing status, the patient's symptoms and the surgery's ability to produce aerosols. All surgeries that require manipulation of the mucosa of the upper aerodigestive tract is considered an aerosol-generating procedure. If the patient has an unknown or negative COVID19 status, is asymptomatic and requires an aerosol generating surgery, the surgical team must wear a PAPR or N95 mask, eye protection, an impermeable gown, and gloves $[9,24,26]$. If the patient has an unknown or negative COVID-19 status, is asymptomatic and requires a non-aerosol generating surgery, the surgical team must wear a surgical mask, eye protection, a gown and gloves $[9,24,26]$. If the patient has an unknown COVID-19 status but is presenting symptoms and requires a nonaerosol generating surgery, the surgical team must wear a PAPR or N95 mask, eye protection, a gown, foot and ankle covers and gloves [9]. For all patients who are COVID-19 positive and require an aerosol generating surgery, the surgical team must wear a PAPR or a N95 mask with eye protection, an impervious gown, foot and ankle covers and gloves [8,24]. The surgery must also be conducted in a designated operating room with negative pressure [25]. If the patient is COVID-19 positive and requires a non-aerosol generating surgery, the surgical team must wear a PPAR or N95 mask, eye protection, a gown and double gloves [9]. PPE information is summarized in Table 3. Guidelines from Cape Town (South Africa) recommend to put a transparent drape over COVID-19 positive patient's head and neck [24]. In an emergency, the patient should always be considered as COVID-19 positive.

6. Who can be in the operating room?

According to all guidelines considered for this review, only essential staff should be in the operating room. ORL-HNS aged of 60 years and older, or with comorbidities are advised not to participate in clinical activi- ties [15]. Residents can be part of the operating team only if they are required for the surgery. Obviously, the most experienced residents are prioritized. Unless otherwise advised by anesthesiologists, ORL-HNS and their residents should not be in the operating room during intubation, because it is an aerosol-generating procedure [6].

In order to minimize contact and virus transmission, some guidelines suggest dividing the otolaryngology team (surgeons and residents) in two sub-teams. Each sub-team works for a pre-established period and then rotates with the other sub-team. If, unfortunately, one sub-team is exposed to SARS-Cov2 virus and requires quarantine, the other sub-team is available to take over $[15,24,25]$.

According to Australian guidelines, surgeries are expected to be longer because of the need for PPE and because of surgical techniques used to reduce aerosols. Thus, a second surgical team should be available if the first surgical team is overworked [28].

7. What surgical techniques modifications are recommended?

In order to limit transmission of SARS-CoV-2 virus, guidelines $[6,23,26,28]$ suggest that medical treatments (radiotherapy, chemotherapy, etc.) should be favored over surgical treatments, when a patient's outcome is not different with either modality. If oncologic surgery is the preferred therapeutic option, it would be important to minimize operating time by promoting primary closure over reconstruction [17]. When reconstruction is absolutely necessary, a pedicled flap should be favored over a free flap if possible [19]. The use of powered electrical instruments such as microdebrider or drill is considered as generating aerosols and have the potential of shedding viral particles from blood [21]. Suctions and electrocautery are also considered as aerosol-generating instruments. Their use should be limited
Table 3 Personal protective equipment choice according to the surgery, the symptoms of the patient and the COVID-19 status

\begin{tabular}{|c|c|c|c|c|}
\hline & \multicolumn{2}{|c|}{ Aerosol-generating procedure } & \multicolumn{2}{|c|}{ Non-aerosol generating surgery } \\
\hline & $\begin{array}{l}\text { Unknown or negative } \\
\text { COVID-19 status }\end{array}$ & $\begin{array}{l}\text { Positive } \\
\text { COVID-19 } \\
\text { status }\end{array}$ & $\begin{array}{l}\text { Unknown or negative } \\
\text { COVID-19 status }\end{array}$ & $\begin{array}{l}\text { Positive } \\
\text { COVID-19 } \\
\text { status }\end{array}$ \\
\hline PAPR & $\mathrm{x}$ & $\mathrm{x}$ & & $\mathrm{x}$ \\
\hline N95 mask & $\mathrm{x}$ & $\mathrm{x}$ & & $\mathrm{x}$ \\
\hline Surgical mask & & & $\mathrm{x}$ & \\
\hline Eye protection & $\mathrm{x}$ & $\mathrm{x}$ & $\mathrm{x}$ & $\mathrm{x}$ \\
\hline Gown & $\mathrm{x}^{*}$ & $\mathrm{x}^{*}$ & $\mathrm{x}$ & $\mathrm{x}$ \\
\hline Gloves & $\mathrm{x}$ & $\mathrm{x}$ & $\mathrm{x}$ & $\mathrm{x}$ \\
\hline Foot and ankle covers & & $\mathrm{x}$ & & \\
\hline $\begin{array}{l}\text { Operating room with } \\
\text { negative pressure }\end{array}$ & & $\mathrm{x}$ & & \\
\hline
\end{tabular}

*An impervious gown 
during surgery when possible $[9,15,19,23,28]$. Instead of powered electrical devices, cold dissection should be practiced [13]. Guidelines from Quebec (Canada) do not recommend the use of transoral robotic surgeries (TORS) during the COVID pandemic because it is an aerosol-generating procedure [5].

Additional local vasoconstriction should be considered during aerosol-generating surgeries [13]. Care must be taken in order to avoid disconnecting suction circuits. The American Academy of Otolaryngology-Head and Neck Surgery guidelines recommends a barrier between the surgical and the anesthetic team, which can limit the spread of the virus between the operating room staff [13].

8. Considering the COVID context, should in-person tumor board meetings still take place?

Most guidelines included in this review do not recommend maintaining in-person tumor board meetings during the COVID pandemic. Although being very relevant but not urgent to the health of patients, most of these meetings cannot respect social distancing recommendations. However, in order to continue to provide the best treatment to patients, most guidelines recommend maintaining tumor board meetings using virtual technologies (teleconference). The only exception is the United Kingdom's guideline, which recommends maintaining the frequency of in-person tumor board meetings, but to reduce the duration and number of participants [17]. Also, guidelines recommend using electronic applications that ensures confidentiality of exchanges [6].

\section{Discussion}

In the unpreceded and rapidly evolving first wave of COVID-19, recommendations were needed in a timely manner. Therefore, prospective data were not yet available on head and neck oncology management. Also, as identified by AGREE scores in this review, the pandemic and urgent context hinders the possibility of building robust guidelines. Statements provided in this study apply to the first and what appears to be the heaviest wave of COVID for now. This review of the literature does not include the recommendations issued or updated after May 2020.

In regard to the second and third waves, we recommend to continue rigorous screening of patients requiring faceto-face consultations. During the first wave, it was advised to reschedule face-to-face appointments for patients with benign and non-cancer diseases and it was recommended to defer in-clinic follow-up. As the COVID-19 pandemic continues, we must ask ourselves as to when should these patients be seen. Indeed, during the first wave, postponing patients with benign and non-cancer diseases was a shortterm solution to what was believed to be a brief pandemic. Now that we understand that we will have to live with this pandemic for a prolonged period of time, these postponed patients must be seen. Face-to-face consultations could be offered in areas where the infection rates are decreasing. Thus, even non-urgent and non-emergent patients could have access to an otolaryngologist, while reducing the risk of transmitting COVID. On the other hand, if infection rates are peaking, face-to-face consultations should once again be avoided. A telemedicine appointment for the postponed patient is still important and can inform on the delay required for the in person consultation.

During the first wave, it was suggested to postpone imaging for asymptomatic and stable oncologic patients. When the second and third wave ensues, some patients cannot be postponed for a year or two. Patients in need of imaging follow-up for oncology follow-up who have been postponed for a cycle or two should be identified and prioritized. There patients could also visit a hospital with low infection rates for a non-urgent imaging follow-up.

Flexible laryngoscopy, an aerosolizing procedure, was postponed for the majority of patients during the first wave. While adequate when initially proposed, this recommendation does not appear to be valid anymore. Considering that this procedure is part of the physical examination, it is becoming more and more difficult to follow the latter recommendation. Guidelines regarding equipment and the amount of people allowed in the room during a flexible laryngoscopy are still relevant.

Unfortunately, most ORL-HNS do not have access to negative pressure rooms in their clinic. However, some institutions have converted regular consultation rooms into negative pressure rooms and most have already a negative pressure room in the emergency or in the intensive care unit, where flexible laryngoscopy of a symptomatic or COVID + patient could take place.

Patients with aggressive cancers still need to be operated quickly despite the pandemic. It is our responsibility to make sure that these patients are operated within the expected time. In the context of limited access to the operating room, many ORL-HNS can find this challenging but should reinforce in their institution the importance of proceeding in a timely fashion as delays could change the patients' survival and functional outcomes. The prioritization recommendations for oncological surgeries are still adequate for the second and third waves.

Resident's training is most likely compromised by the COVID-19 pandemic. Indeed, there is a reduction in operating room activity and in ambulatory clinic activity. However, it is possible to increase the amount of virtual teaching lessons and scientific activities such as journal clubs. 
Additionally, although residents interact with a reduced number of patients, they can take more time to review cases with their attending. Programs might consider using simulators to improve knowledge and skills, especially for junior residents. The reduced surgical activities in elective cases and procedures require a more focused and objectiveoriented teaching in the operating room. Programs might consider modifying rotation schedules to prioritize rotations in hospitals with low COVID-19 infectious rates and hence higher surgical activity.

Transoral robotic surgeries (TORS) are not recommended in guidelines elaborated in Quebec, Canada even though they play a significant role in the management of head and neck cancers. Considering the important role or TORS in the diagnosis of unknown primaries and its role as an alternative to radiation therapy for early-stage oropharynx cancers, we recommend a personalized decision-making process before precluding its use.

Reevaluation and modifications of the guidelines are expected as the pandemic evolves and more evidence becomes available. We recognize that many countries are now in the decreasing part of the curve but present recommendations could be useful in the context of an inherent second and third wave.

\section{Areas of controversies}

As the threat of being contaminated by the COVID-19 becomes inherent to the medical practice, protocols are being integrated to ensure a safe environment and the correct use of PPE becomes established. In this setting the role and level of participation of residents needs to be reassessed as they still have a need to learn and we have a responsibility to teach.

Many guidelines downsize the role of surgery in the pandemic era sometimes recommending non-surgical treatment over surgical treatment as it appears that head and neck cancer surgeries such as transoral laser or robotic surgery are aerosol-generating and as such, are considered unsafe in this pandemic era. This needs to be weighed against the daily back and forth travel from home to the hospital for 6 to 7 weeks of patients receiving radiation therapy which might increase the risk of contamination of the patients and the staff involved in their care. For advanced cancers, the choice of bimodal therapy can also be a dilemma as surgery and radiation therapy have the previously mentioned disadvantages, whereas radiation therapy with concomitant chemotherapy involve a potential decrease in immunity for the patient.

Regarding reconstruction after oncological surgery of the head and neck, most guidelines recommend the use of a pedicled flap over a free flap mostly because it reduces the surgical time and reduces the personnel in the OR [19]. Some pedicled flaps have shown lower hospitalization rates, shorter operative times and lower revision rates compared to free flaps without compromising function and quality of life when used appropriately [30]. In some instances, it could, therefore, reduce the use of resources and might reduce the risk of exposure to the virus. However, the use of free flaps remains necessary for some defects such as circumferential pharyngeal defects or mandibulectomy involving the symphysis and parasymphysis.

The duration of the pandemic is still unknown and the occurrence of a second and third wave is to be expected. At the beginning of the pandemic, delaying treatments of slowly progressive cancers seemed rational but how long can it be done without a significant impact on patients' survival and quality of life? As the pandemic persists, it is necessary to improve our surgical planning in order to increase the number of surgeries performed and, therefore, continue to operate patients with slowly progressive cancers. ORL-HNS and institutions need to adapt to the pandemic and find ways to maintain the surgical flow rate while maintaining a safe environment for healthcare professionals and patients.

\section{Conclusion}

Head and neck oncology is a service which often requires time-sensitive and emergent procedures that must be addressed during the COVID-19 pandemic. However, ORL-HNS are at great risk of contracting SARS-CoV-2 virus due to the high viral load in the upper airway. Patient appointments and surgical prioritization must be adjusted in order to respect pandemic requirements. High-grade malignancies should, however, not be delayed, due to potential serious consequences. COVID-19 testing and adequate PPE precautions are essential in operating rooms, due to the fact that many head and neck interventions are aerosol-generating procedures. Additional data would be required to fully understand clinical impacts of the pandemic on head and neck oncology patients and safety of the whole otolaryngology team. More robust guidelines and recommendations are to be expected.

\section{Appendix}

See Annex 1-Table 4. 


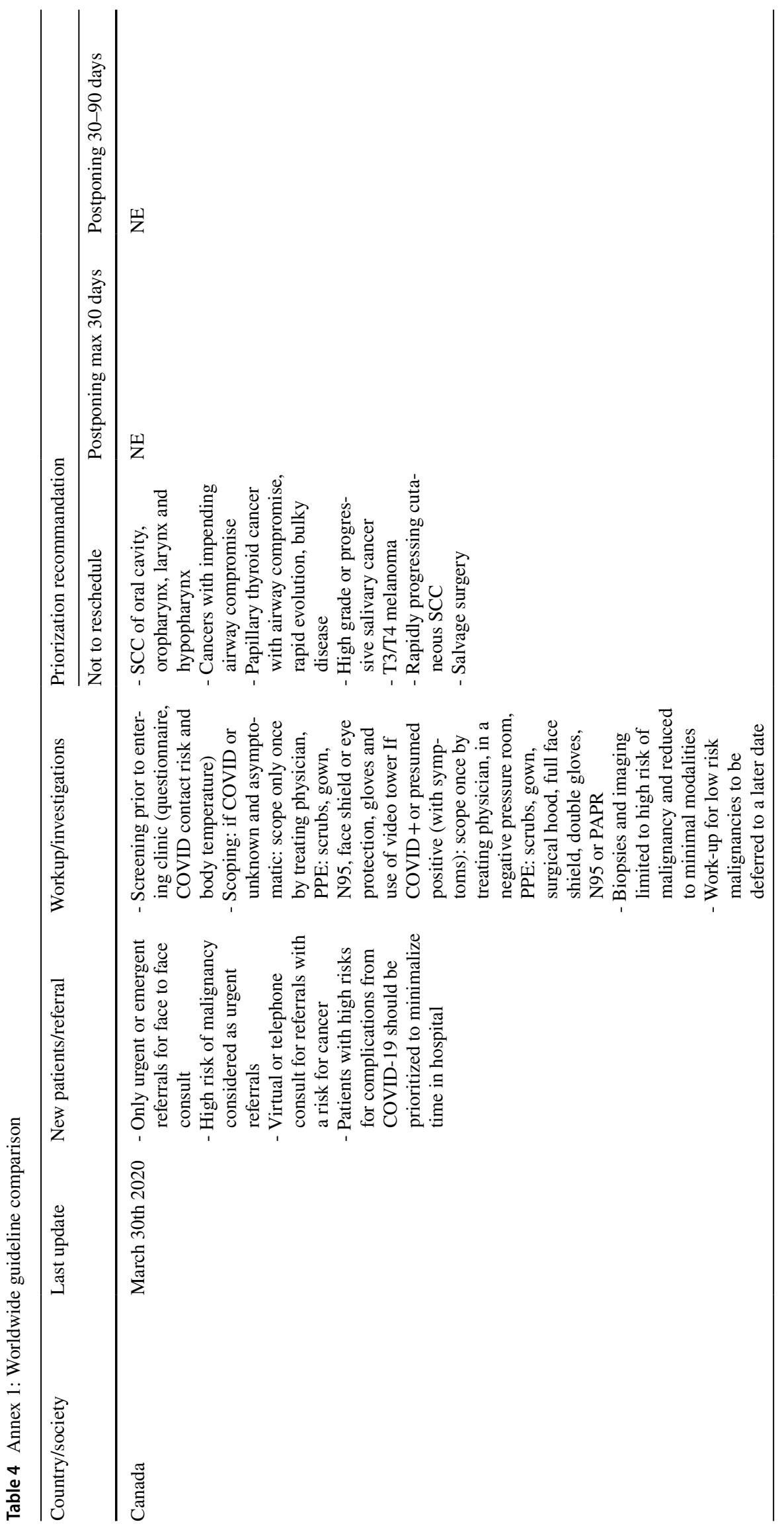




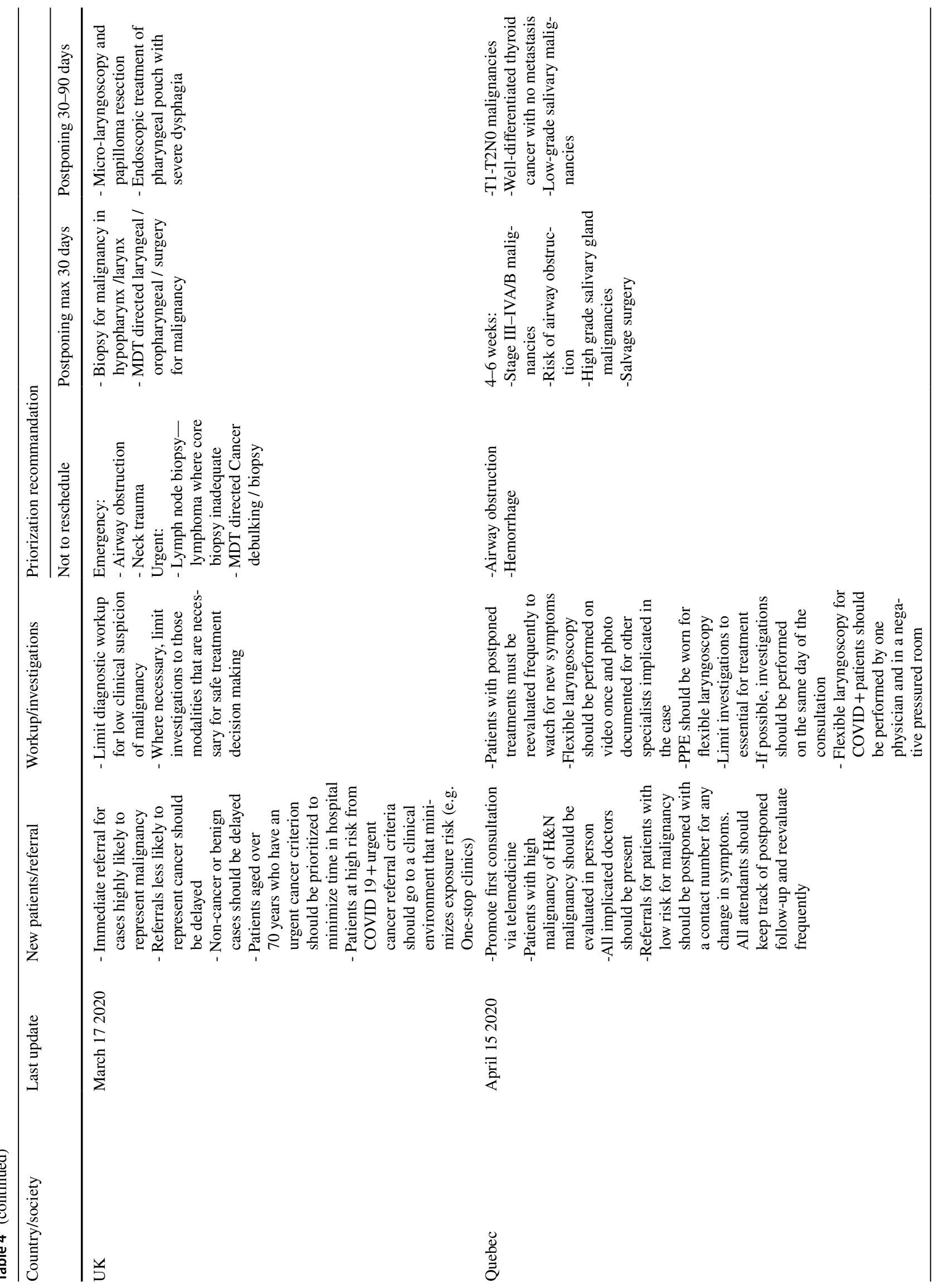




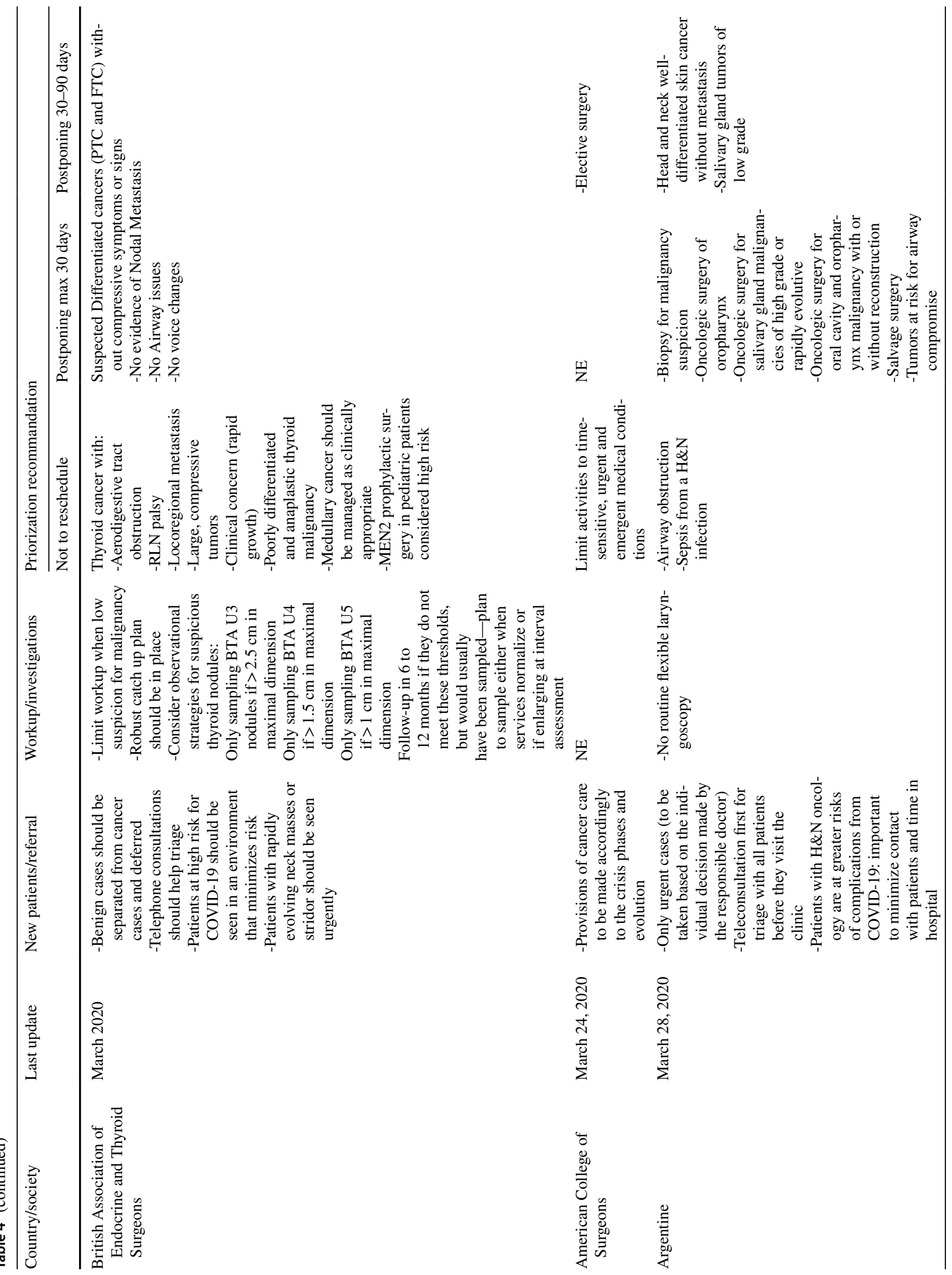




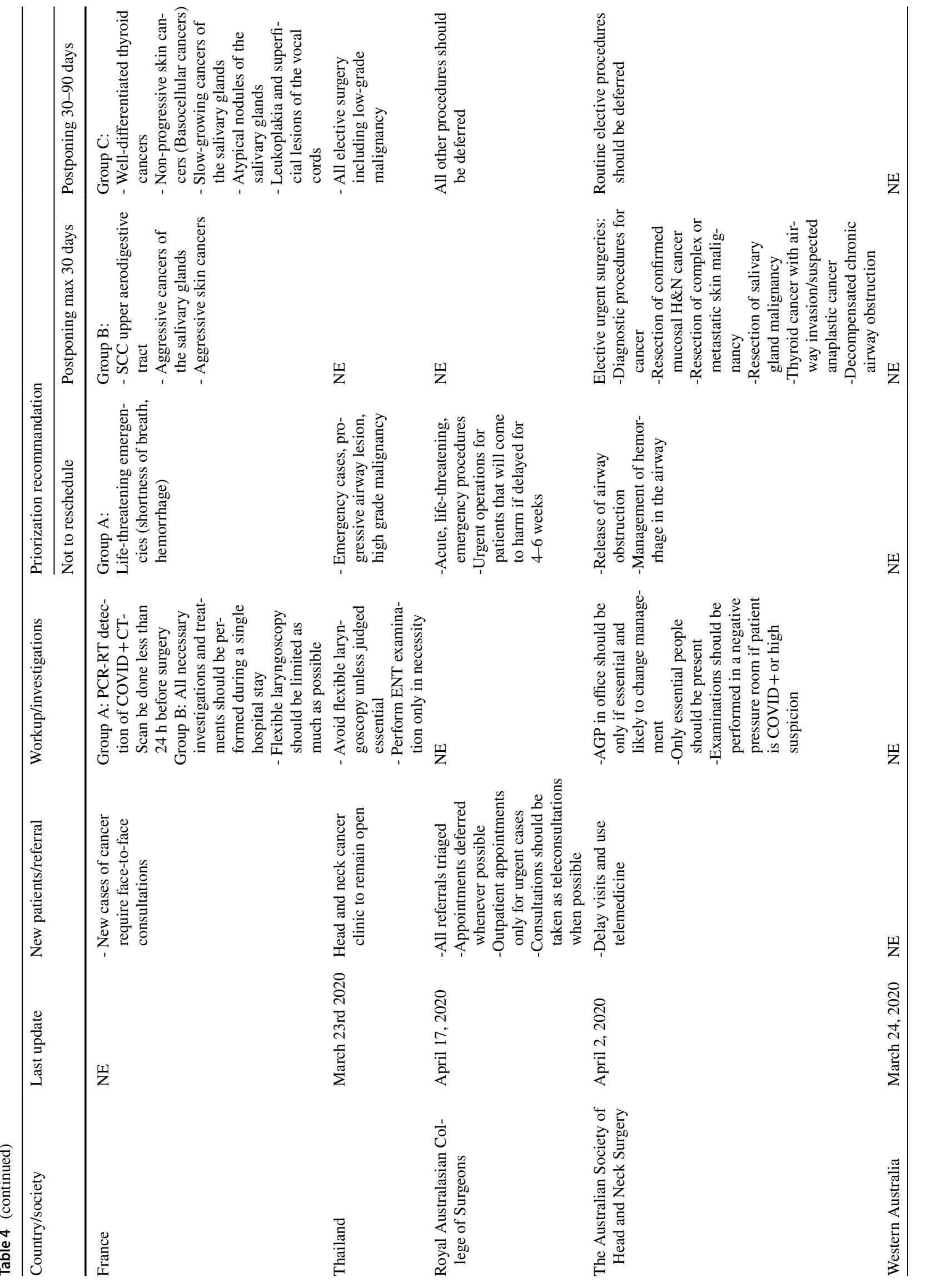




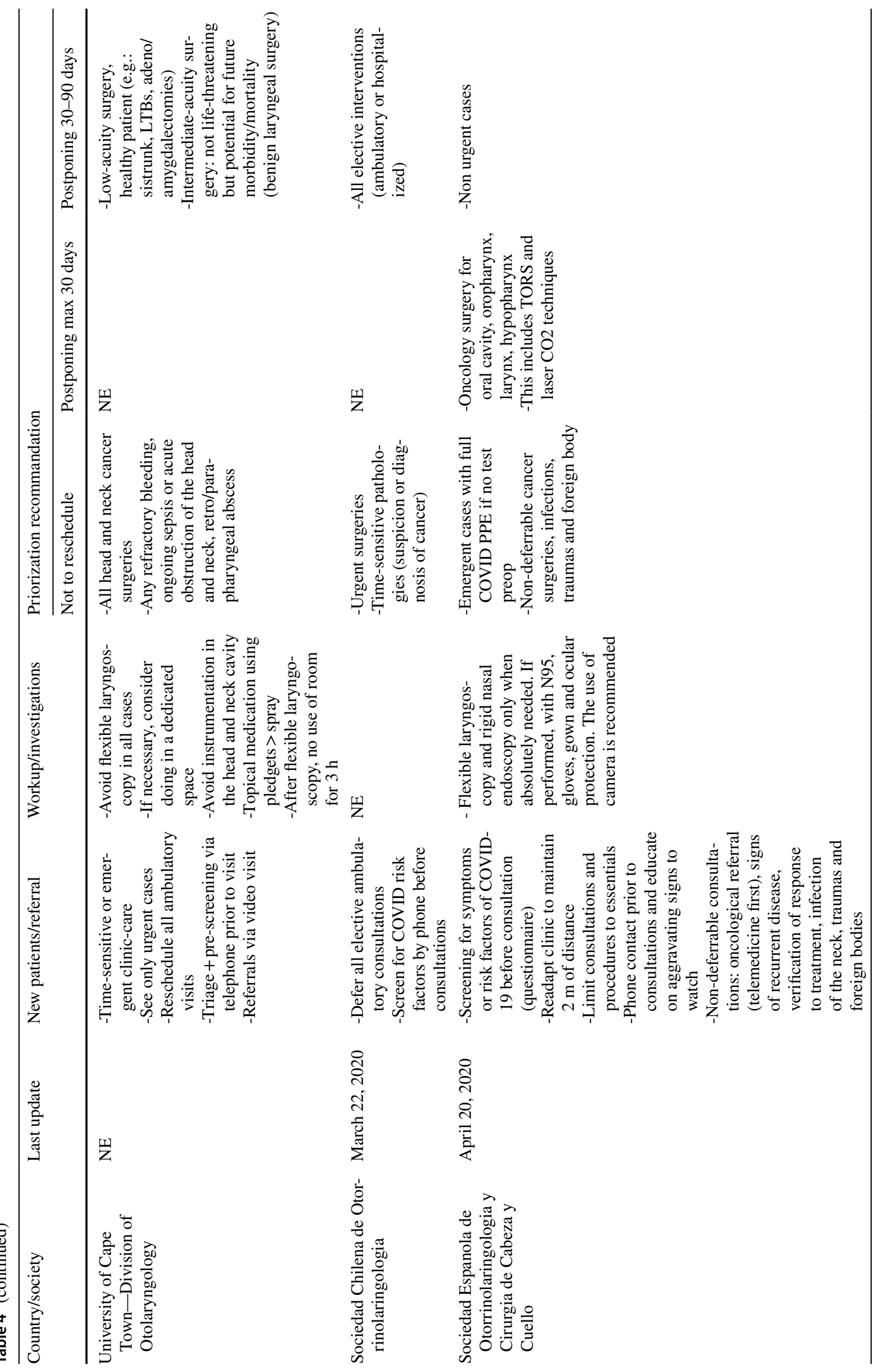




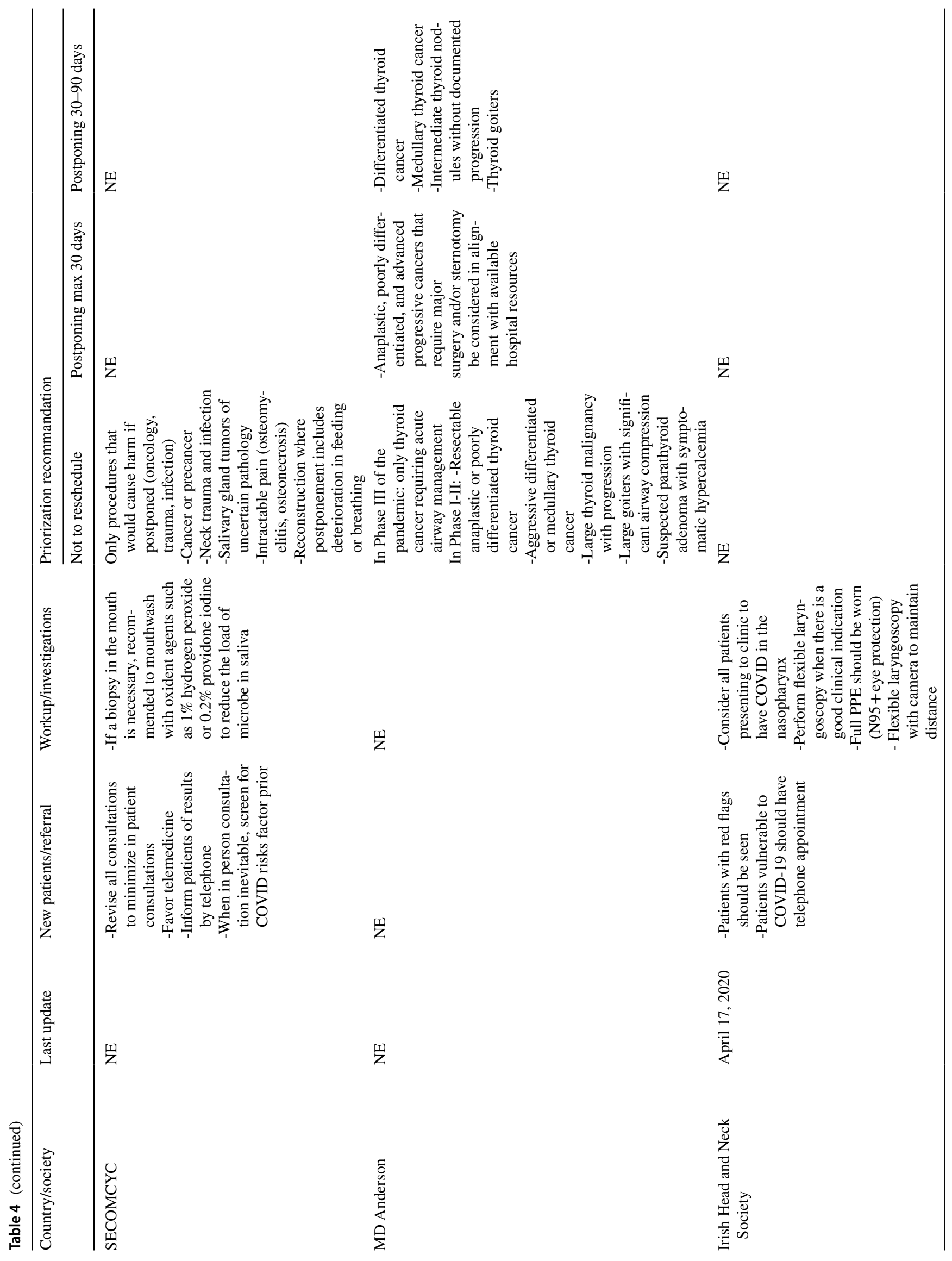


924

European Archives of Oto-Rhino-Laryngology (2022) 279:907-943

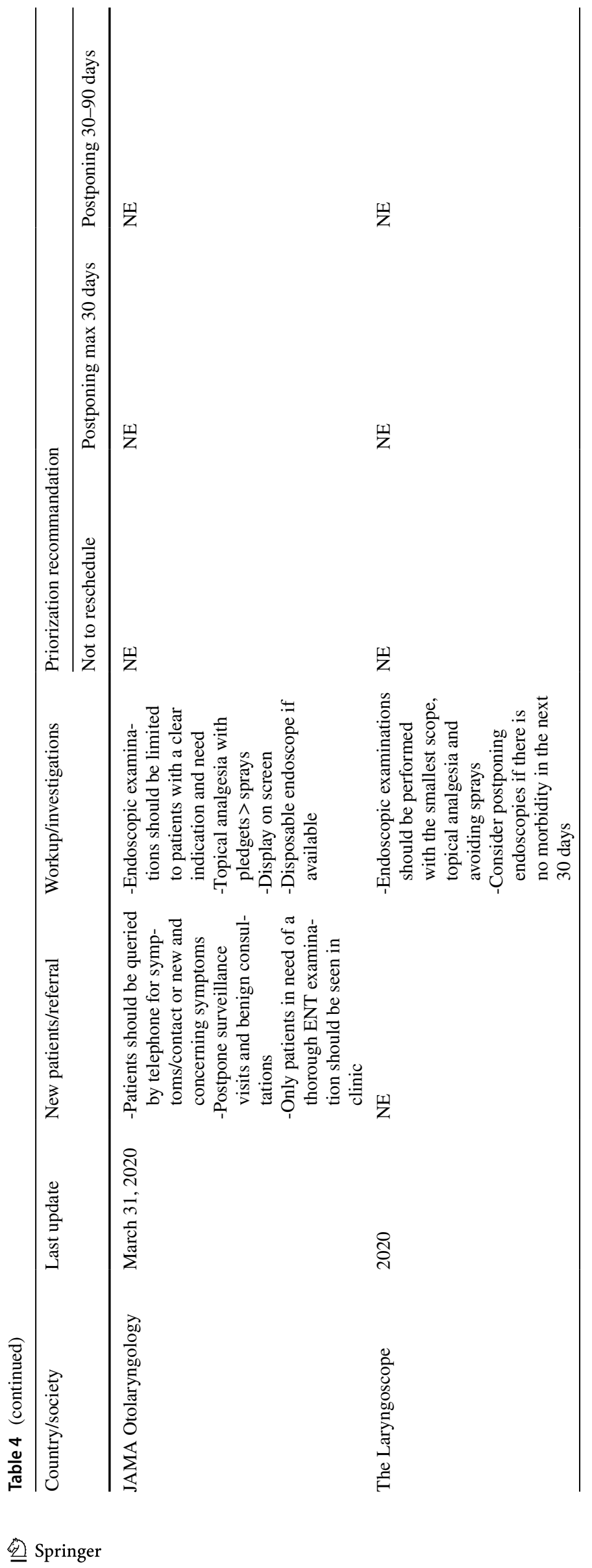




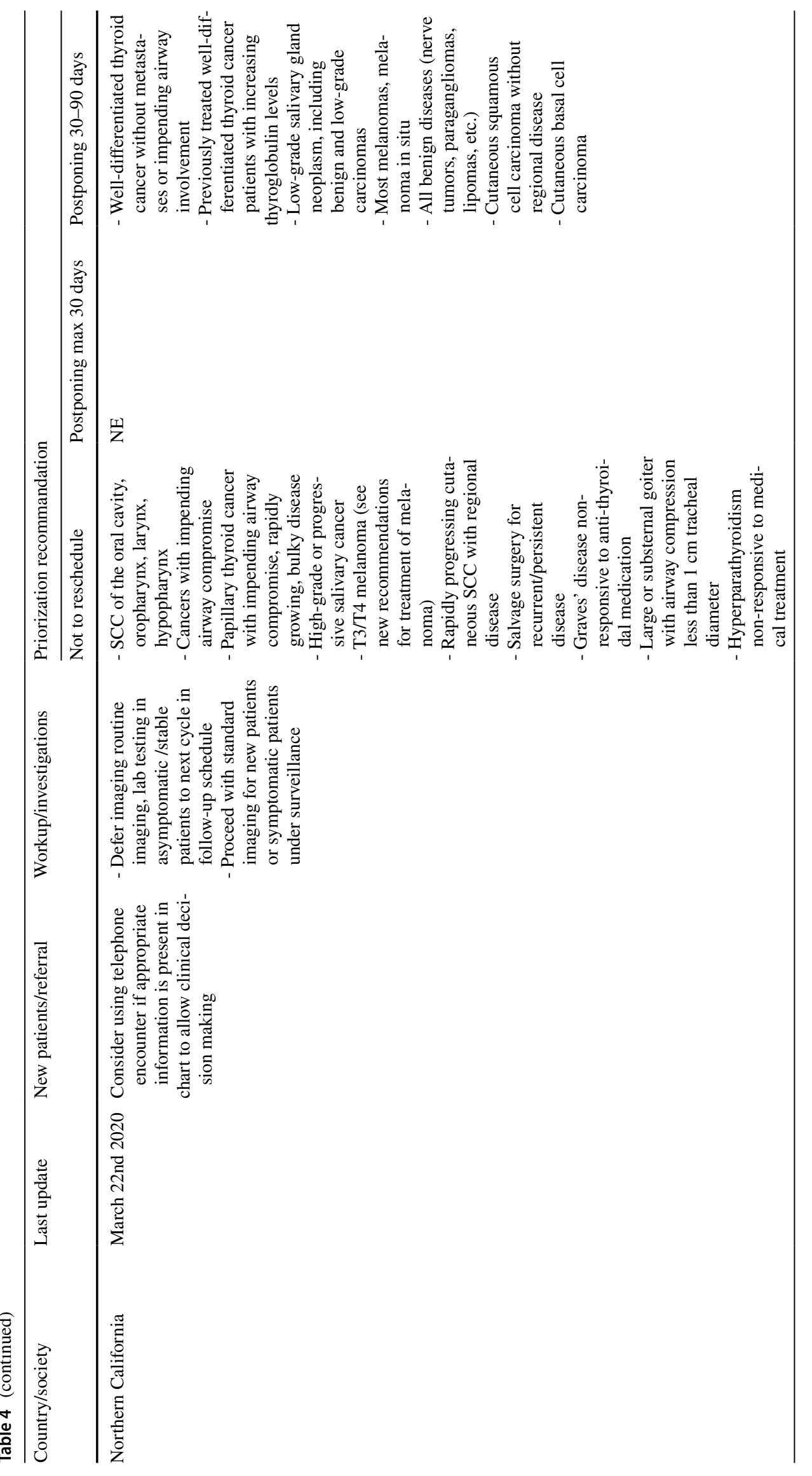




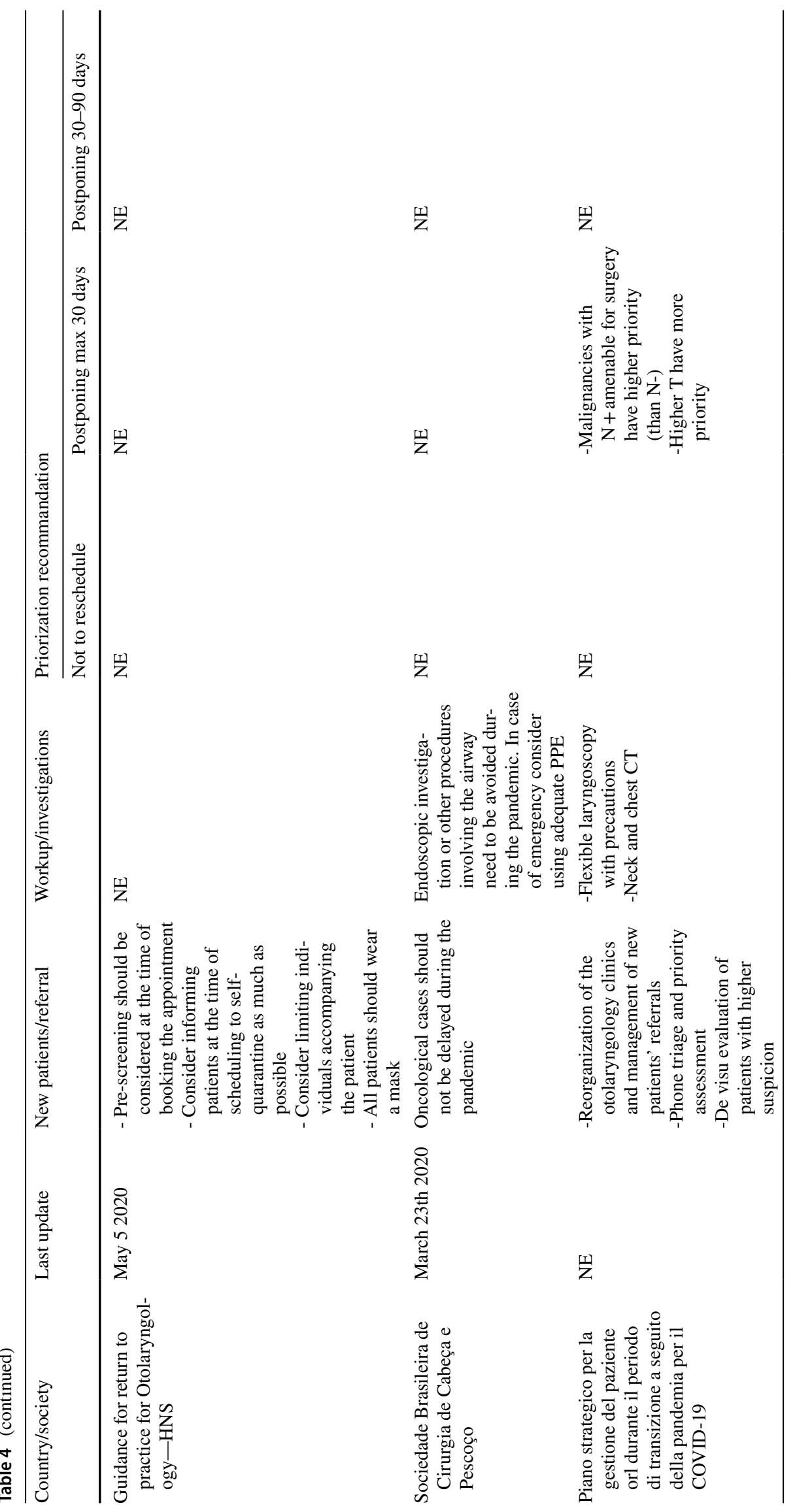




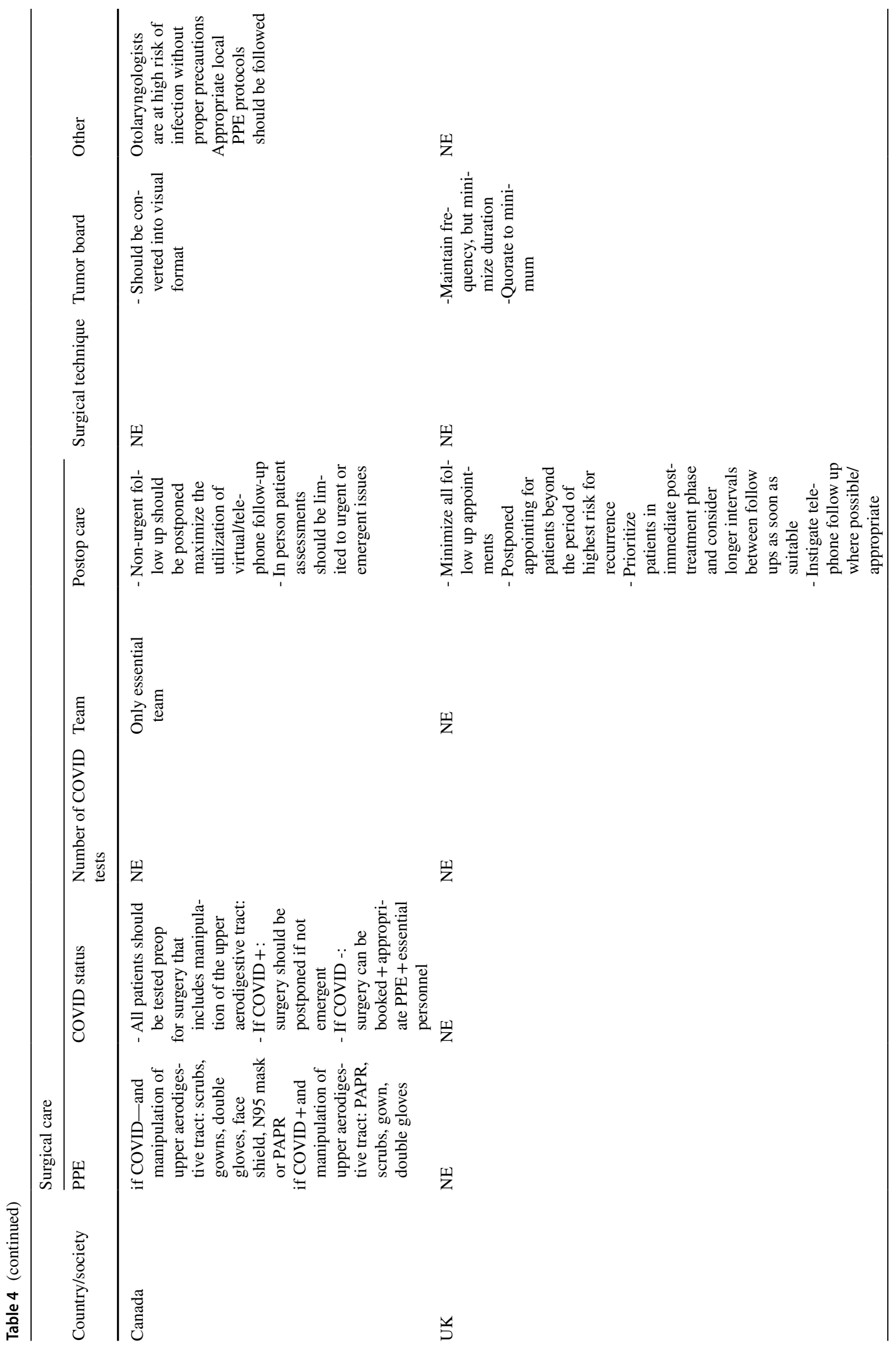




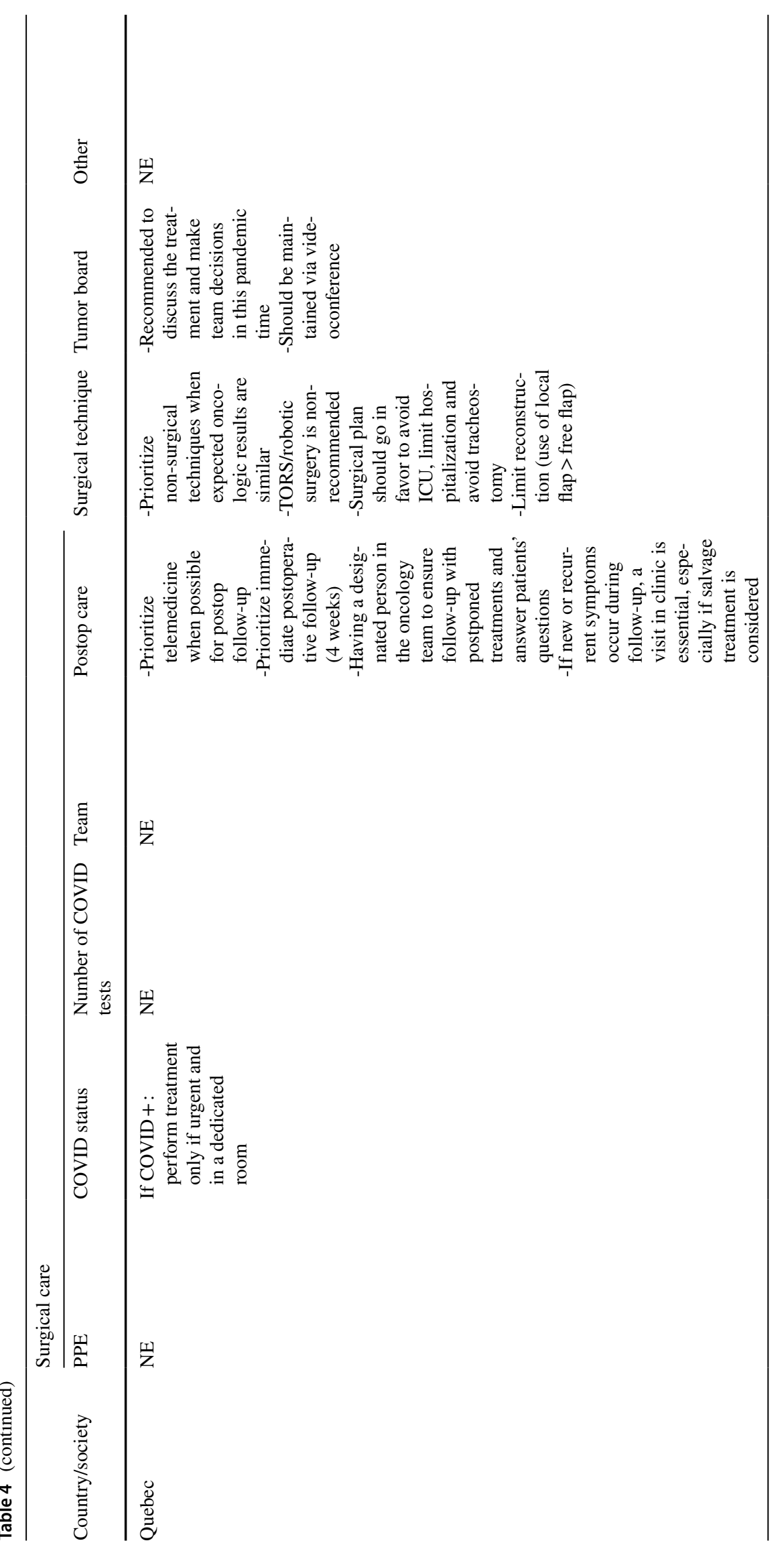




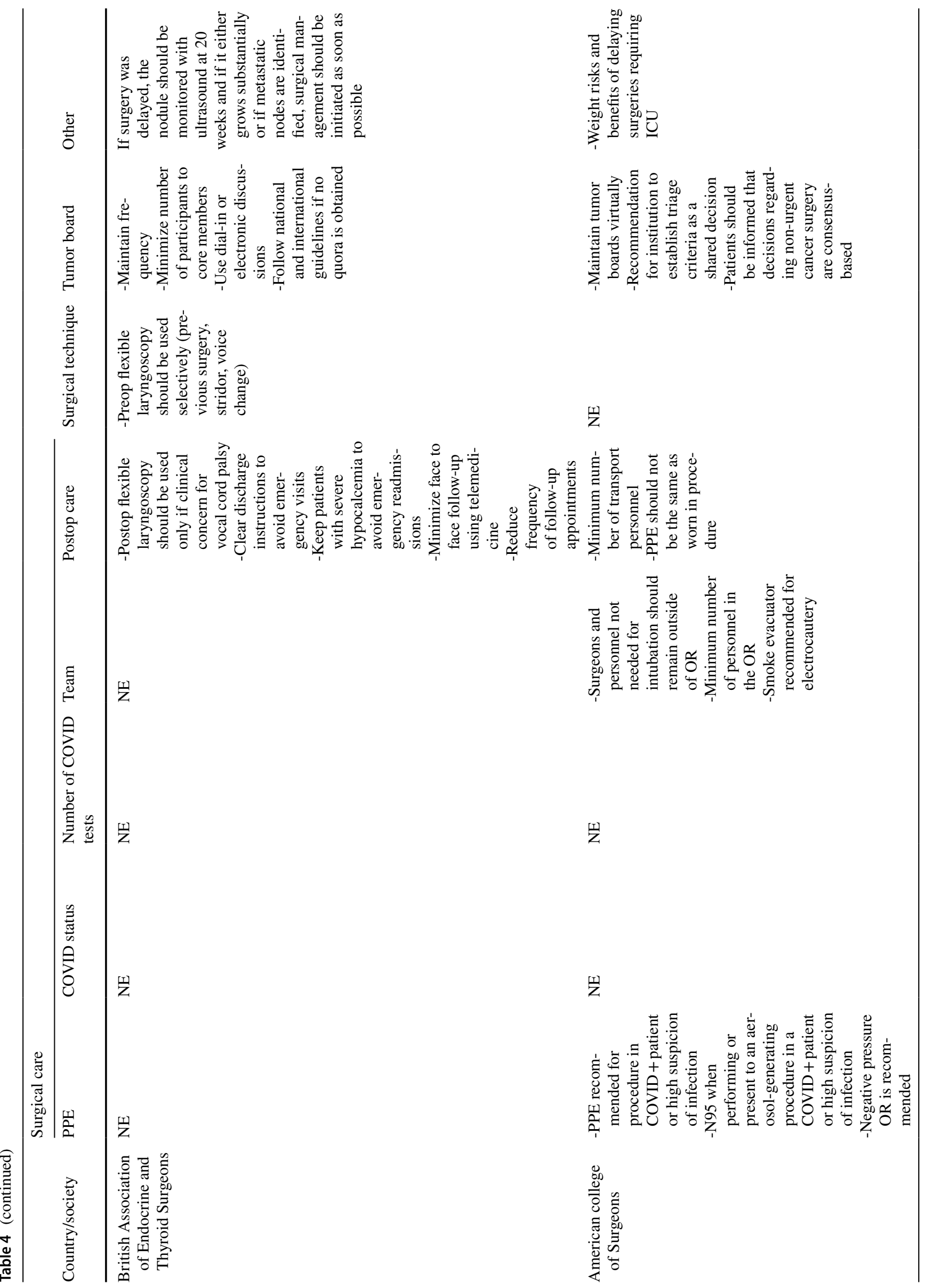




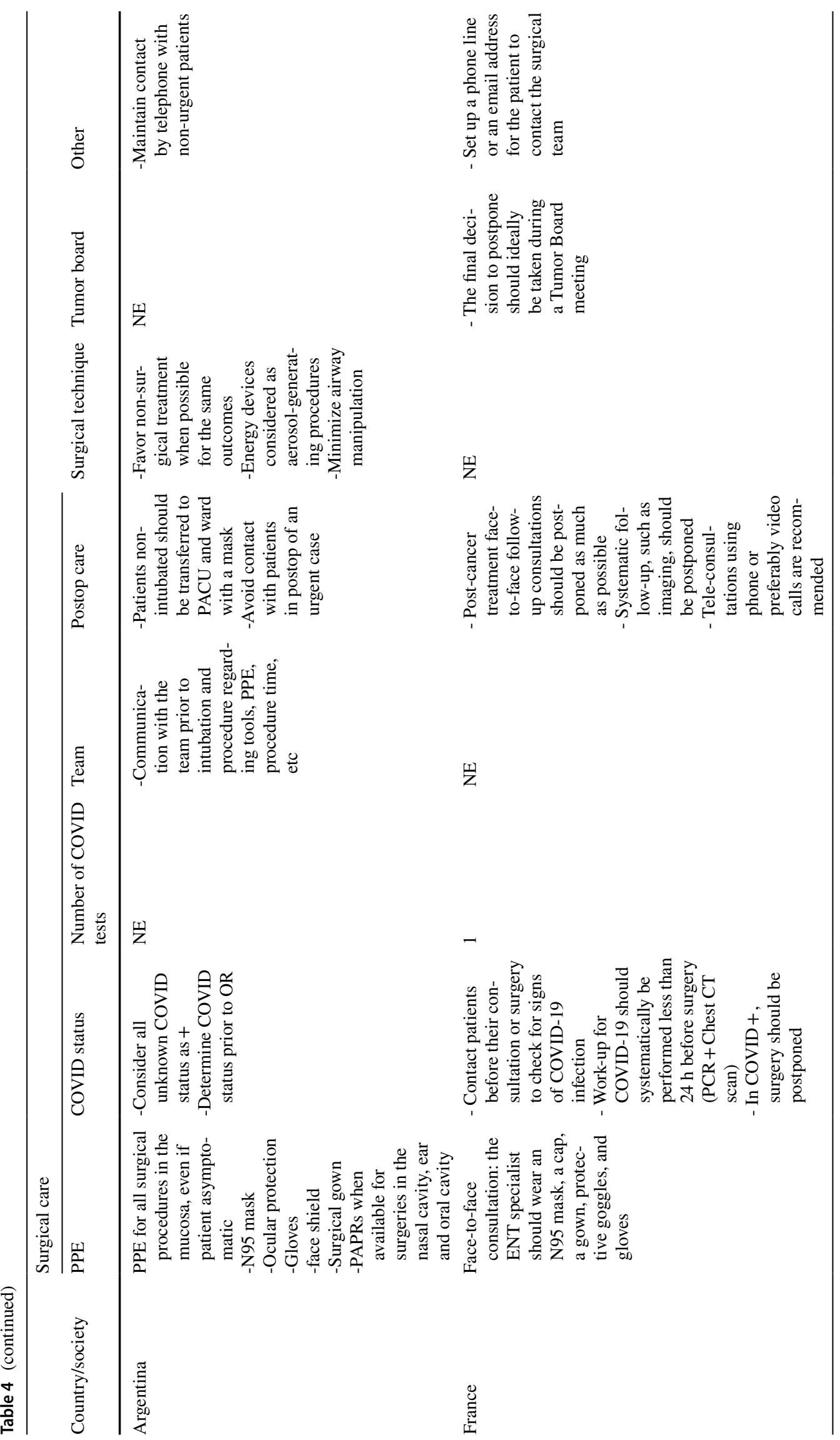




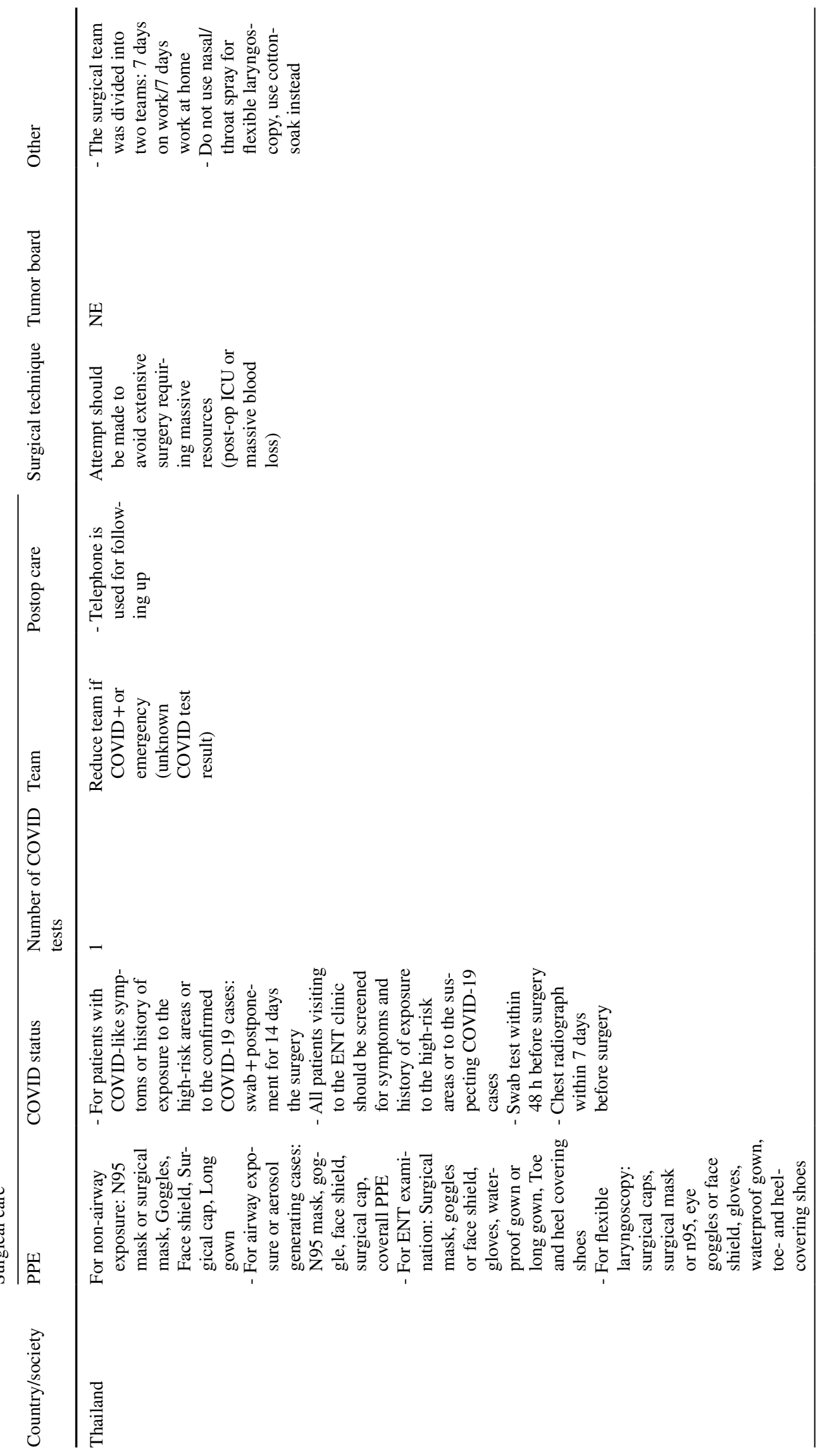




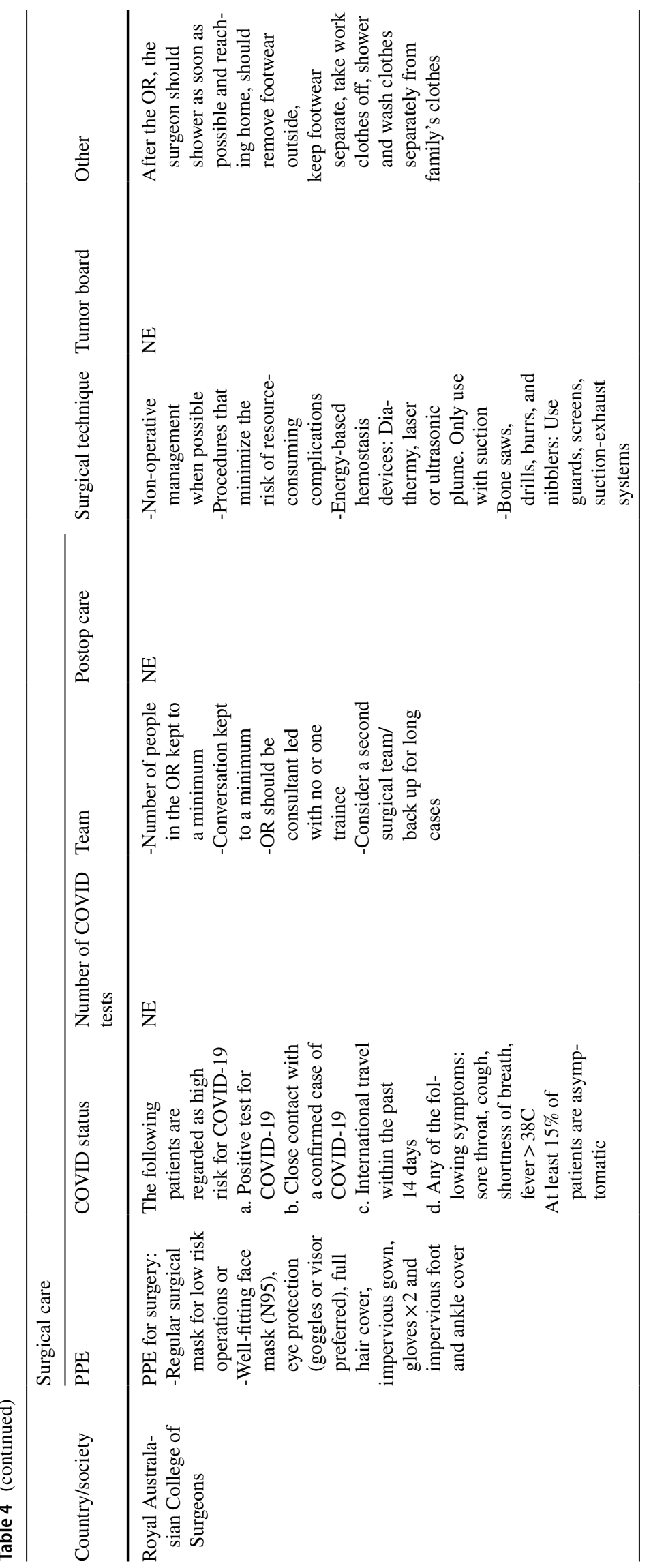




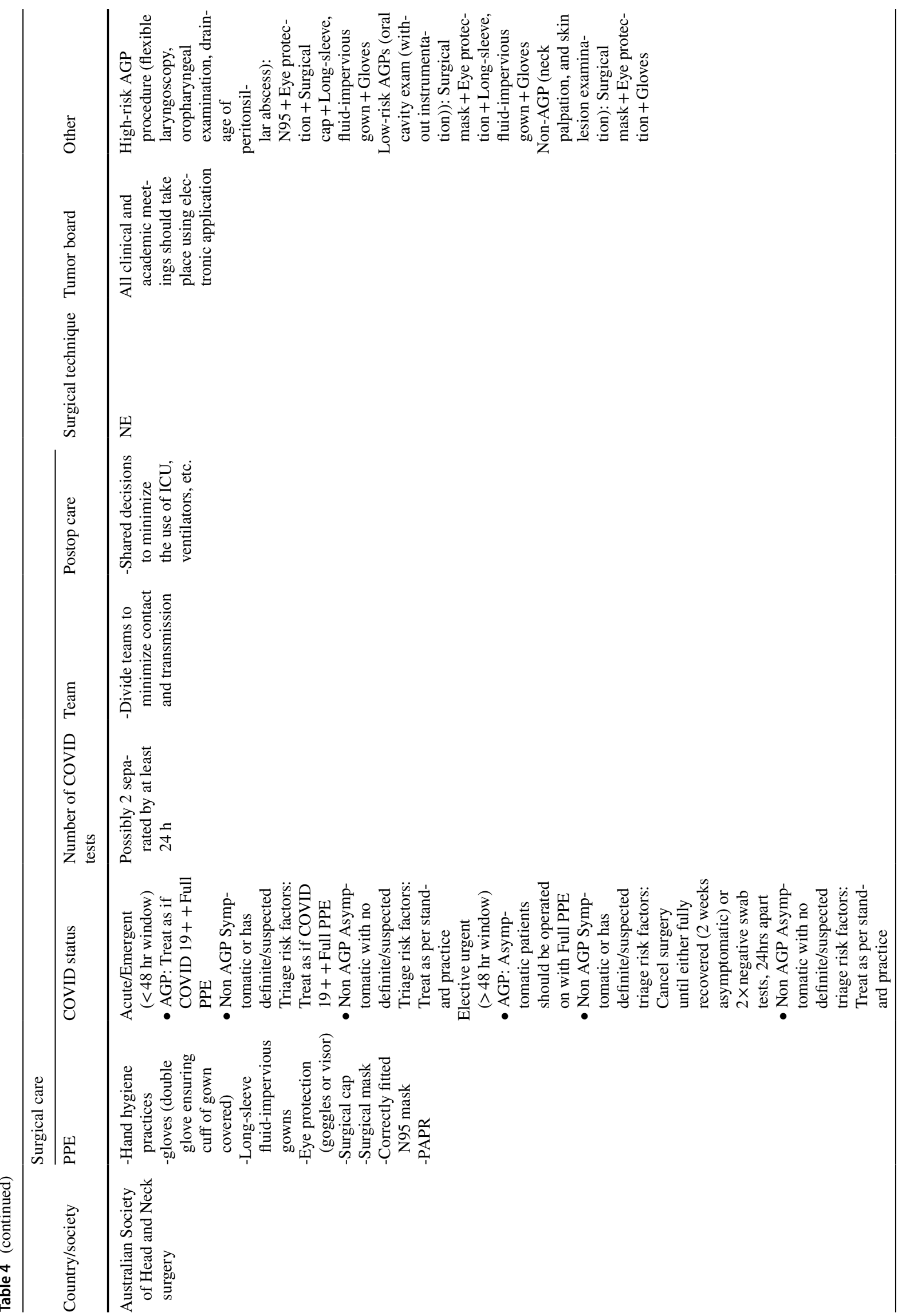




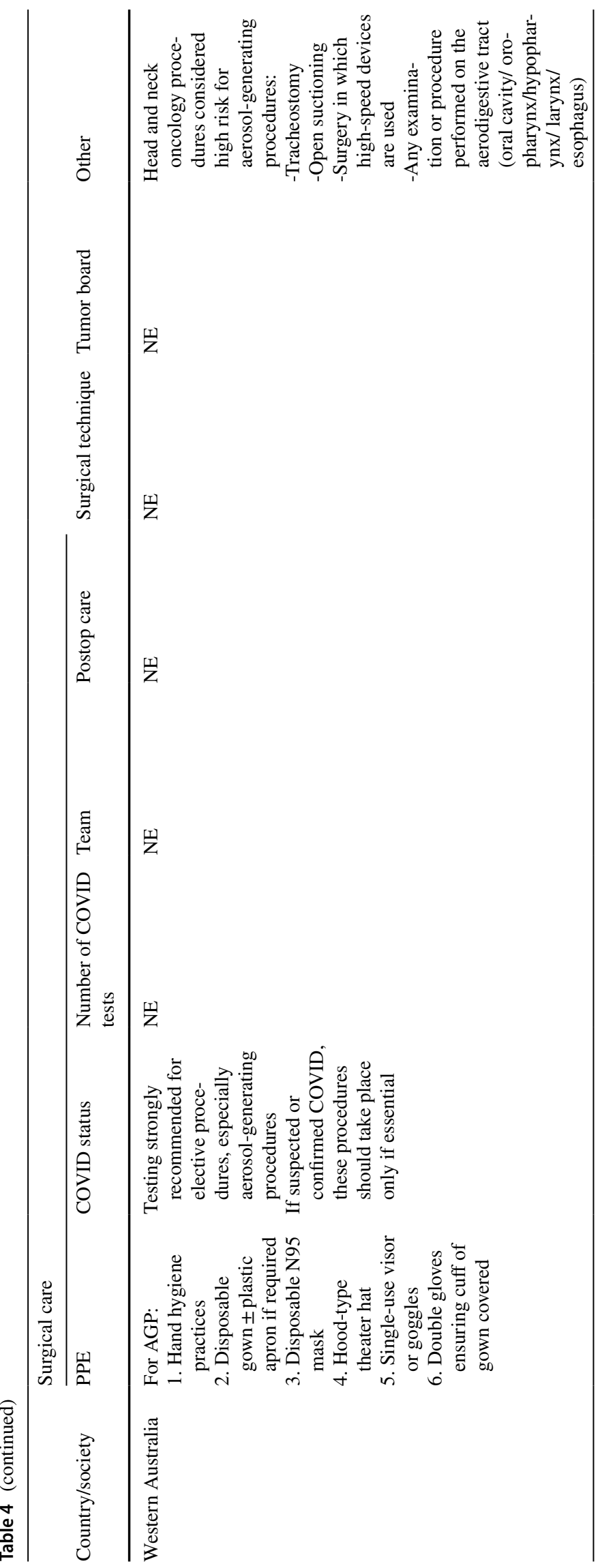




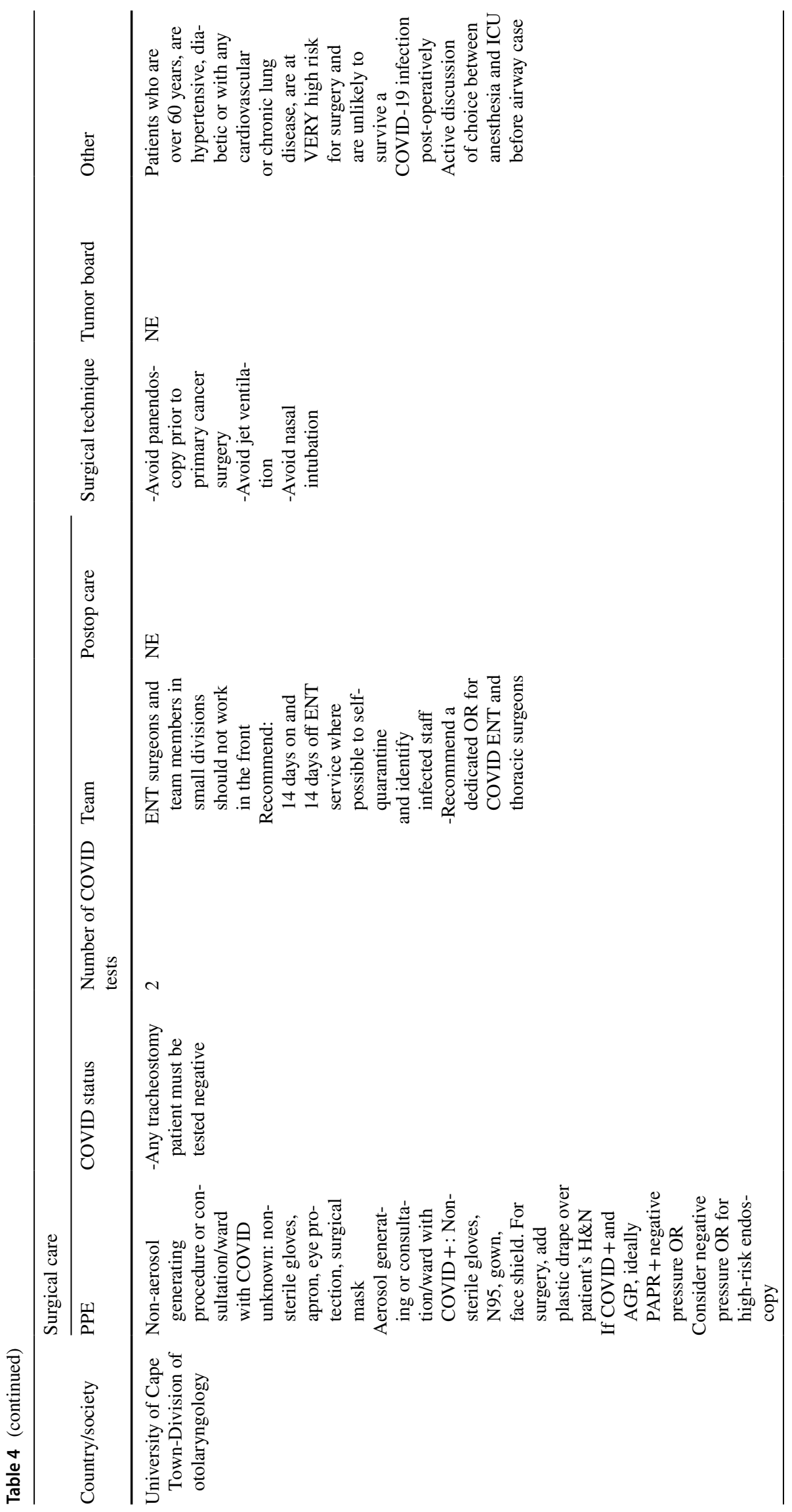




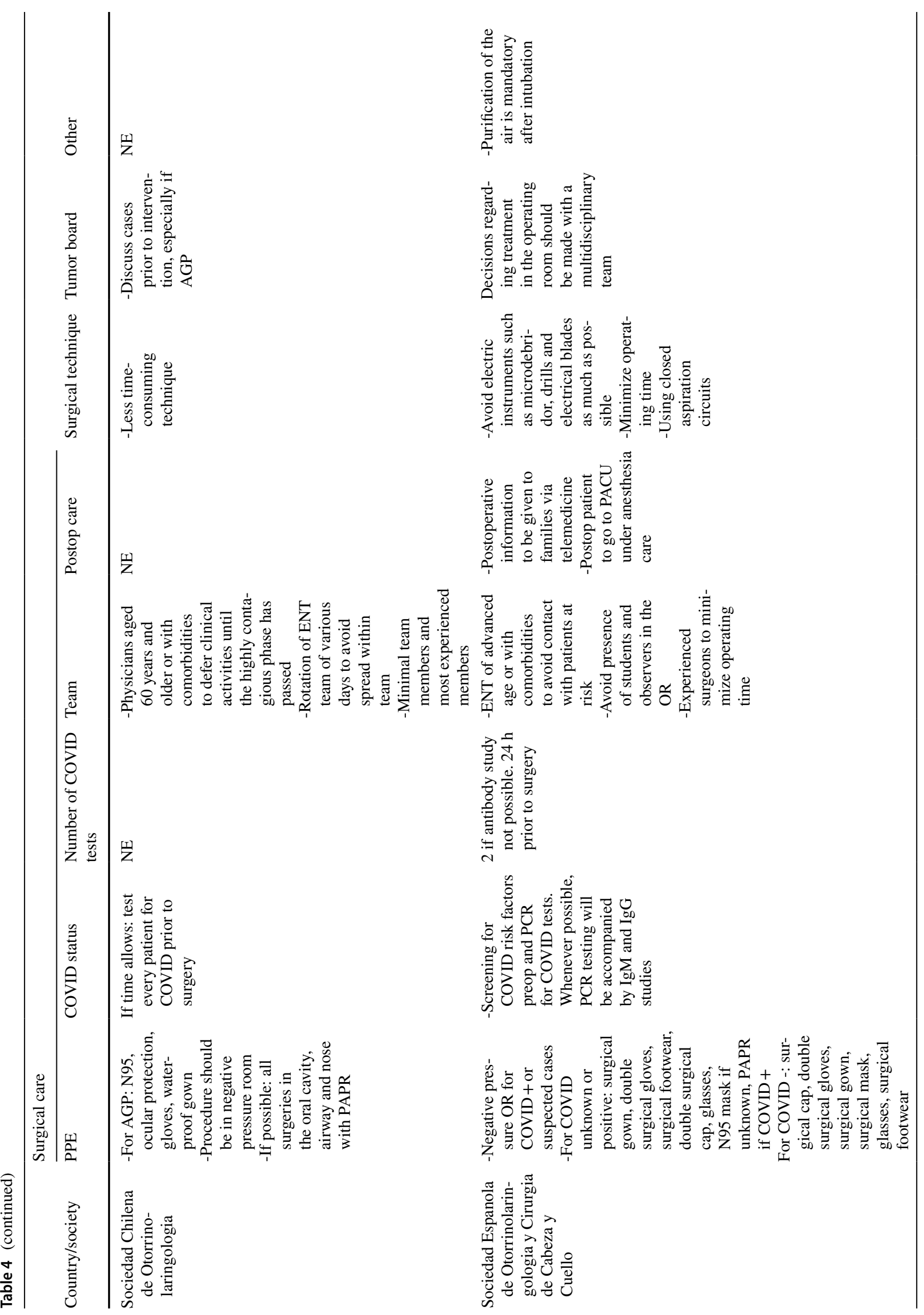




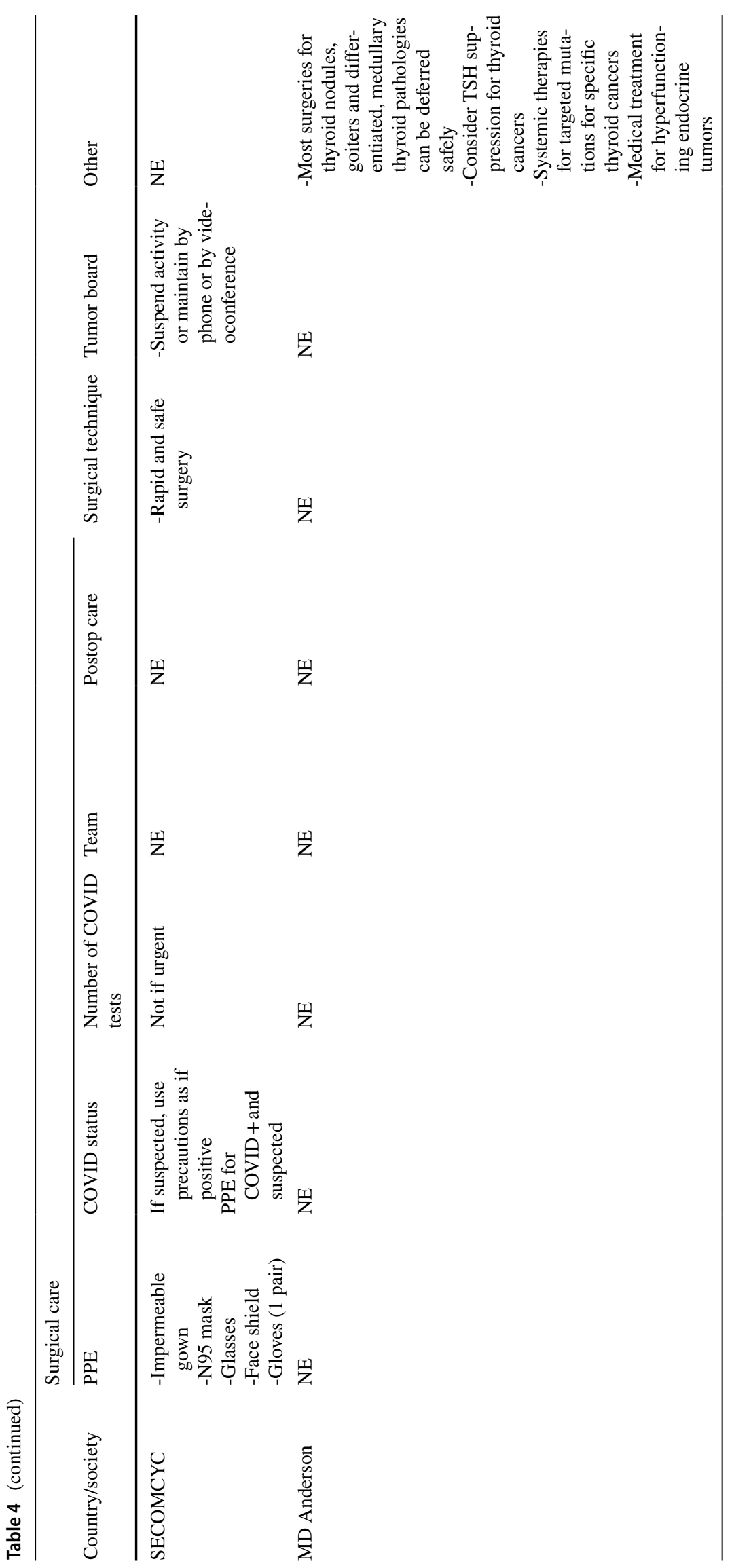




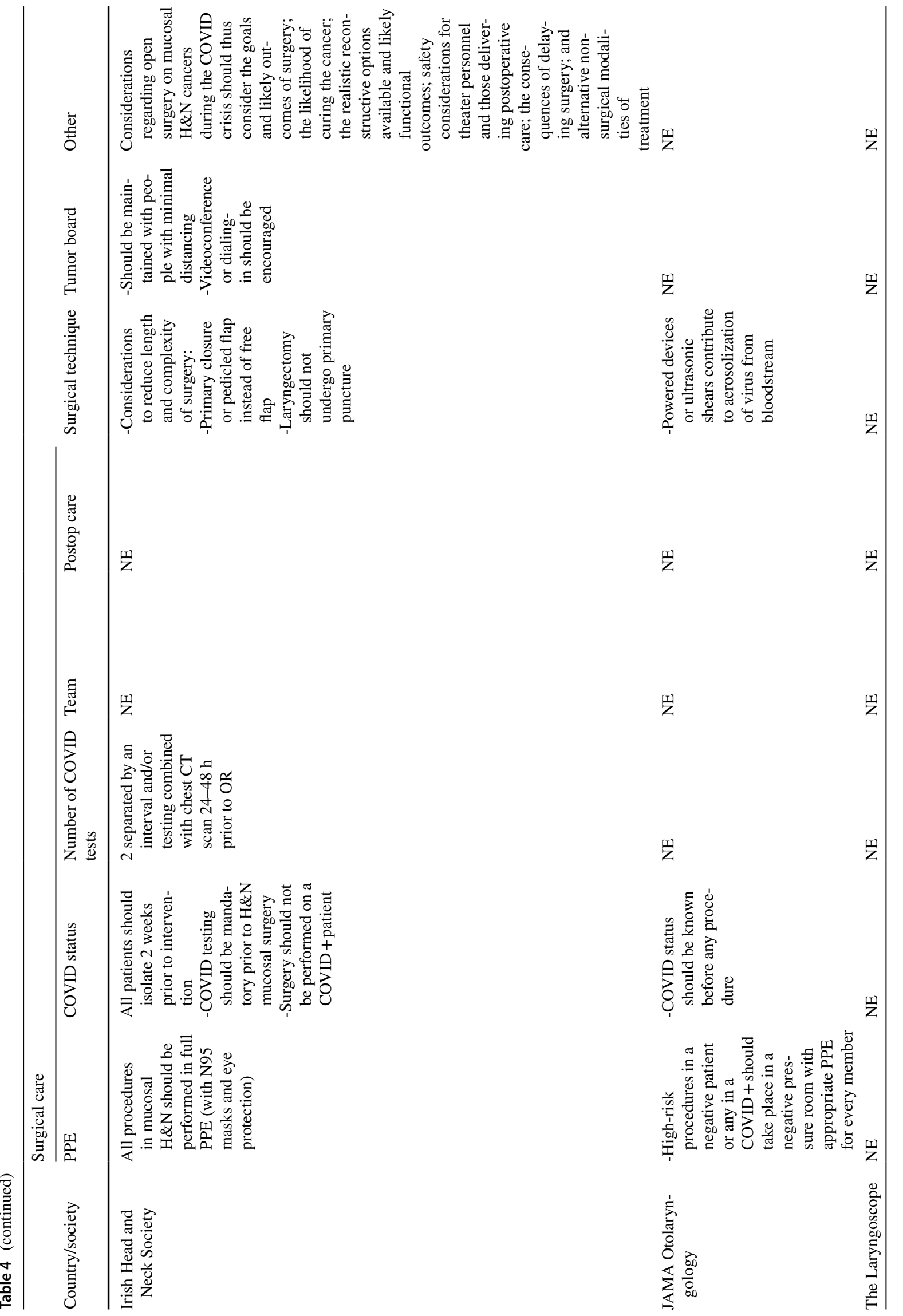


European Archives of Oto-Rhino-Laryngology (2022) 279:907-943

939

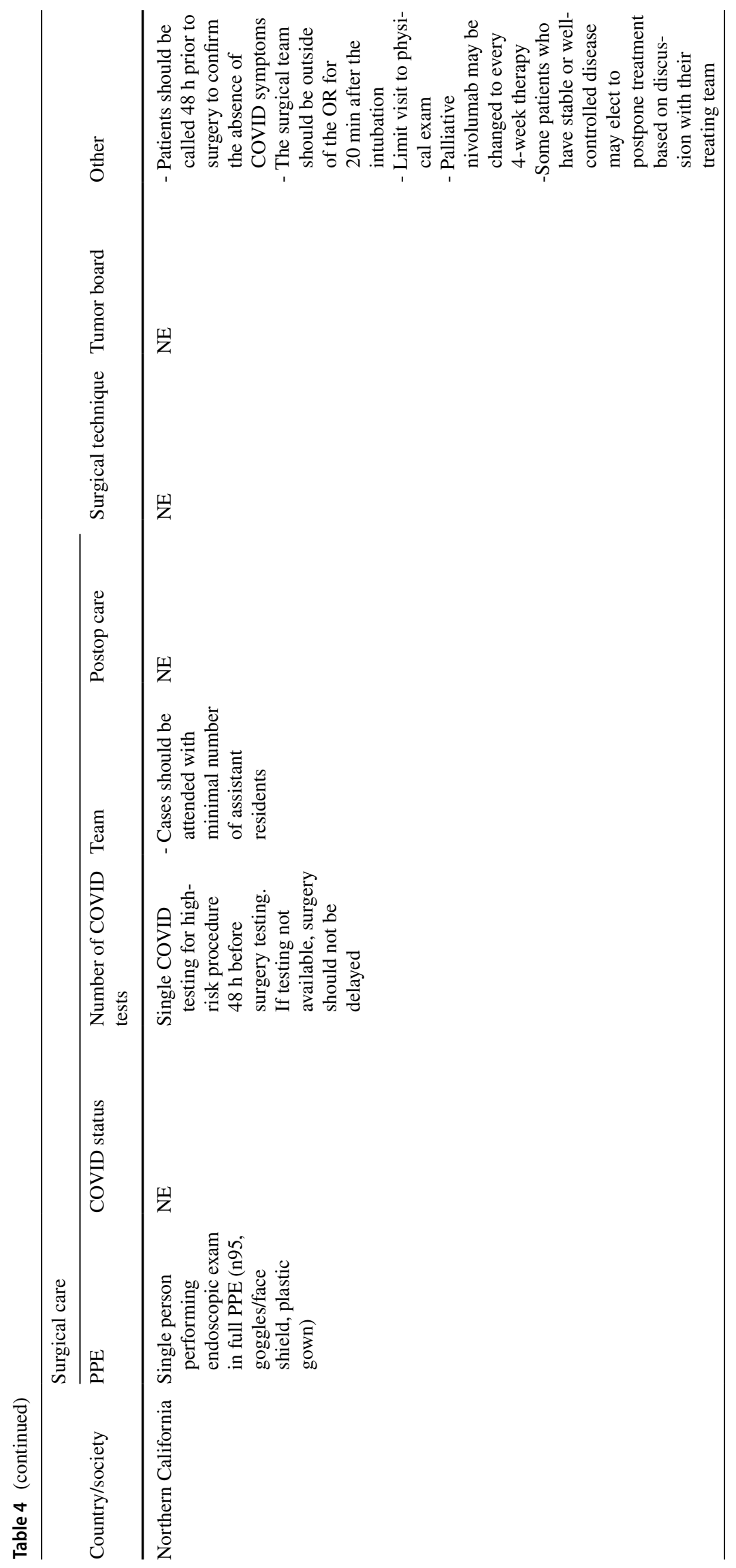

包 Springer 


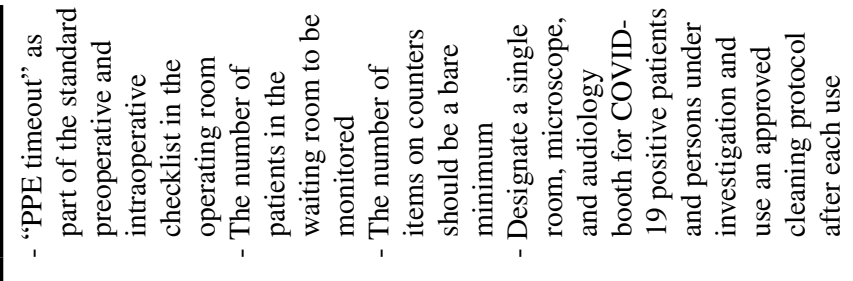

政

㞱

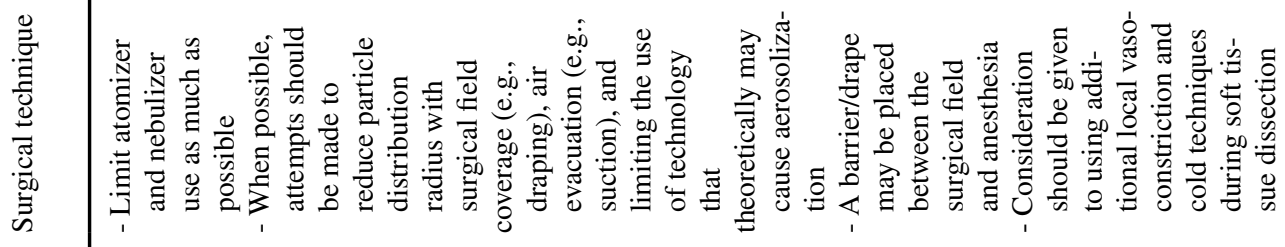

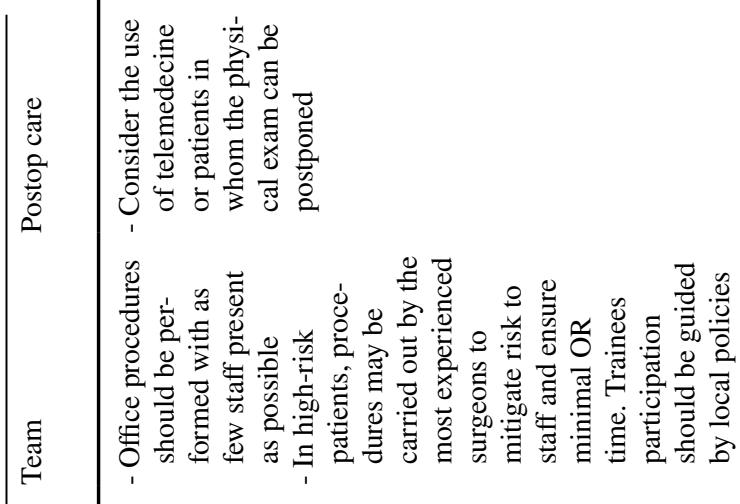

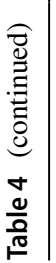

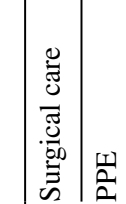

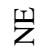

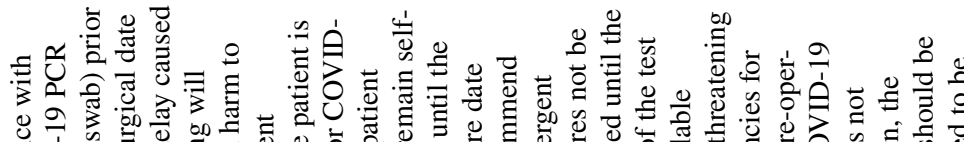

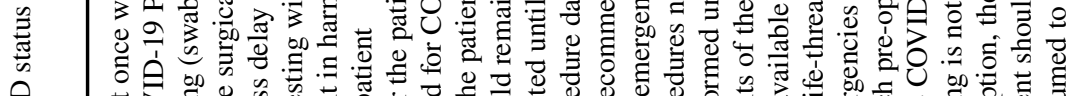

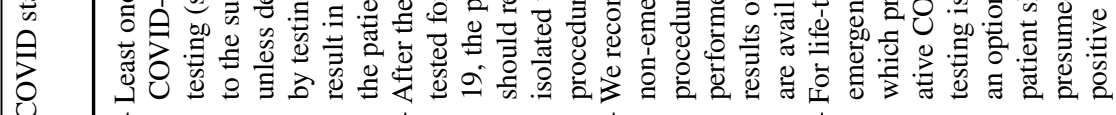

e

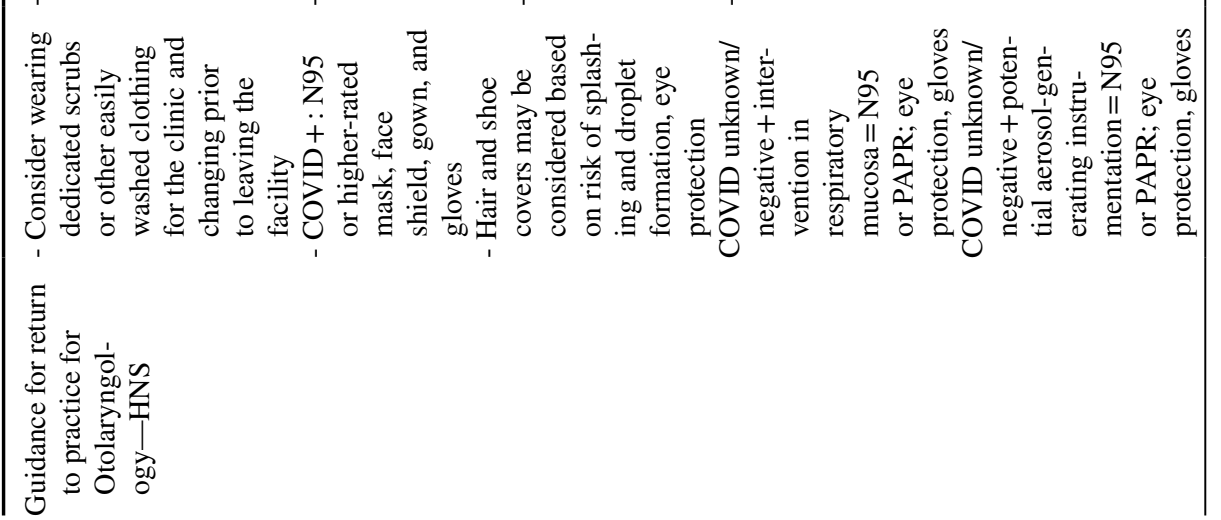




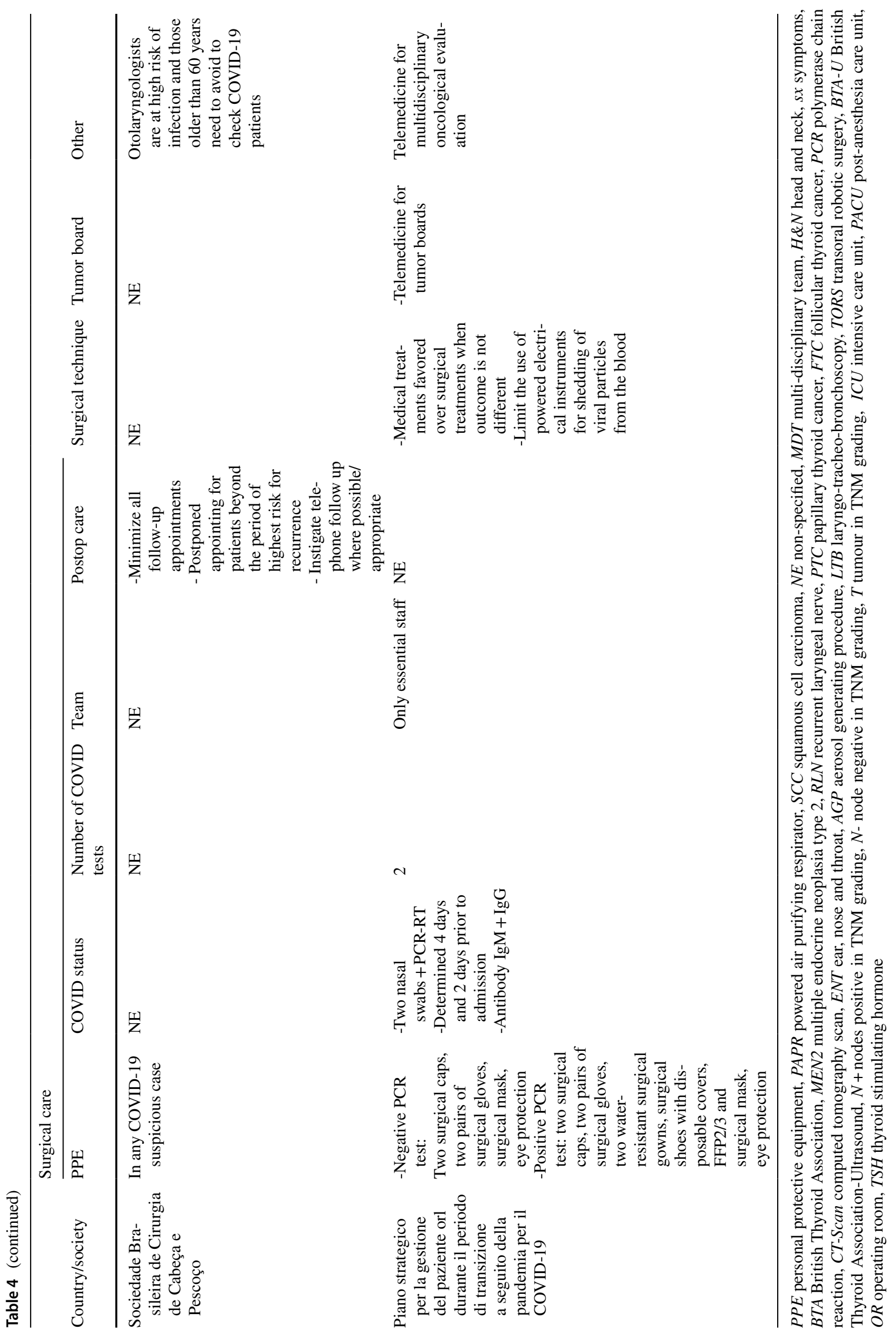


Funding This research did not receive any specific grant from funding agencies in the public, commercial, or not-for-profit sectors.

\section{Declarations}

Conflict of interest Authors do not have any conflict of interest to disclose.

\section{References}

1. Sowerby LJ, Stephenson K, Dickie A, Di Lella FA, Jefferson N, North H, De Siati RD, Maunsell R, Herzog M, Nandhan R, Trozzi M, Dehgani-Mobaraki P, Melkane A, Callejas C, Miljeteig H, Smit D, Reynoso DD, Moura JE, Hermansson A, Peer S, Burnell L, Fakhry N, Chiesa-Estomba C, Çelebi OO, Karpischenko S, Sobol S, Sargi Z, Patel ZM (2020) International registry of otolaryngologist-head and neck surgeons with COVID-19. Int Forum Allergy Rhinol. 10(11):1201-1208. https://doi.org/10.1002/alr.22677 (Epub 2020 Aug 24)

2. Liberati A et al (2009) The PRISMA statement for reporting systematic reviews and meta-analyses of studies that evaluate health care interventions: explanation and elaboration. J Clin Epidemiol. https://doi.org/10.1371/journal.pmed.1000100

3. Moher D et al (2009) Preferred reporting items for systematic reviews and meta-analyses: the PRISMA Statement. Open Med. https://doi.org/10.1371/journal.pmed.1000097

4. Using the PICOTS Framework to Strengthen Evidence Gathered in Clinical Trials-Guidance from the AHRQ's Evidence-based Practice Centers Program. https://www.fda.gov/media/109448/ download

5. Canadian Association of Head \& Neck Surgical Oncology (CAHNSO) (2020) Guidelines for management of Head \& Neck Cancer during the COVID-19 Pandemic. https://www. entcanada.org/wp-content/uploads/CAHNSO-Cancer-Mx-Guide lines-COVID-19-Apr-3-2020-.pdf

6. Ministère de la Santé et des Services sociaux (2020) Recommandations pour la priorisation des patients en contexte de pandémie de COVID-19-Volet Cancers ORL/tête et cou. https:// www.msss.gouv.qc.ca/professionnels/documents/coronavirus2019-ncov/PJ7_Recommandations_cancers-ORL_200415.pdf

7. American College of Surgeons (2020) COVID 19: Considerations for Optimum Surgeon Protection. https://www.facs.org/-/media/ files/covid19/considerations_optimum_surgeon_protection.ashx

8. Jozaghi Y, Zafereo ME, Perrier ND et al (2020) Endocrine surgery in the Coronavirus disease 2019 pandemic: Surgical Triage Guidelines. Head Neck J Sci Spec Head Neck. https://doi.org/10. 1002/hed.26169

9. Givi B, Schiff BA, Chinn SB et al (2020) Safety recommendations for evaluation and surgery of the head and neck during the COVID-19 pandemic. JAMA Otolaryngol Head Neck Surg. https://doi.org/10.1001/jamaoto.2020.0780

10. Neelaysh Vukkadala Z, Jason Qian F, Holsinger C, Patel ZM, Rosenthal E (2020) COVID-19 and the otolaryngologist: preliminary evidence-based review. Laryngoscope. https://doi.org/ 10.1002/lary.28672

11. Gurushanthaiah D, Wang K, Moon S, Butt F, Ledgerwood L, O'Toole T, Fong B, Meltzer C (2020) HN cancer care guidelines during COVID-19 epidemic. https://www.entcanada.org/wp-conte nt/uploads/NCAL-HN-Oncologic-Surgery-in-COVID-Era_v3.pdf

12. American College of Surgeon (2020) COVID 19: Elective Case Triage Guidelines for Surgical Care. https://www.facs.org/-/ media/files/covid19/guidance_for_triage_of_nonemergent_surgi cal_procedures_otolaryngology.ashx
13. American Academy of Otolaryngology—Head and Neck Surgery (2020) Guidance for return to practice for Otolaryngology-Head and neck surgery. https://www.entnet.org/sites/default/files/uploa ds/guidance_for_return_to_practice_part_one_final_050520.pdf

14. Lautaro A, Ana L, Ana Laura C, Florencia F, Romina D, Pita Elián G, Pérez C, Rosende M, Victoria Demarchi M, Boccio MC, Pérez Raffo G (2020) Protocolo interno COVID-19 para consultas y prácticas del servicio de Otorrinolaringología. http://faso.org. ar/imagenes/covid/protocolo_italiano-17-4.pdf

15. Sociedad Chilena de otorrinolaringologia (2020) Recomendaciones de la socieded chilena de otorrinilaringologia, medicina y cirugia de Cabeza y cuello para el ejercicio de la especialidad durante pandemia covid-19 (SARS-CoV-2). http://www.coleg iomedico.cl/wp-content/uploads/2020/04/recomendaciones-medic os-COVID-SOCHIORL.pdf

16. Sociedade brasileira de cirurgia de cabeça e pescoço (2020) Recomendação da SBCCP sobre atendimento médico na ; Especialidade durante epidemia de covid-19. http://sbccp.org.br/recom endacao-da-sbccp-sobre-atendimento-medico-na-especialidadedurante-epidemia-de-covid-19/

17. Initial guidance for head and neck cancer management during Covid-19 pandemic in consultation with ENT UK (2020) https:// www.entuk.org/sites/default/files/Initial\%20guidance\%20for\% 20head\%20and $\% 20$ neck\%20 cancer\%20management $\% 20$ during $\%$ 20Covid\%20\%281\%29.pdf

18. British association of endocrine \& thyroid surgeons (2020) BAETS statement on COVID-19 and Thyroid Cancer Services. https://www.endocrinology.org/media/3571/baets-statement-oncovid-19-and-thyroid-cancer-services.pdf

19. Irish Head and Neck Society (2020) Considerations on H\&N during COVID-19. https://www.ahns.info/wp-content/uploads/2020/ 03/Irish-Head-and-Neck-Society-considerations-on-COVID-20-320.pdf

20. Fakhry N, Schultz $P$, Morinière $S$ et al (2020) French consensus on management of head and neck cancer surgery during COVID-19 pandemic. Eur Ann Otorhinolaryngol Head Neck Dis 137(3):159-160

21. Sociedad Espanola de Otorrinolaringologia y Cirurgia de Cabeza y Cuello (2020) Estrategias para el manejo del paciente orl durante la fase de control de la pandemia por la covid-19. https:// seorl.net/wp-content/uploads/2020/04/ESTRATEGIAS-PARAEL-MANEJO-DEL-PACIENTE-ORL-DURANTE-LA-FASEDE-CONTROL-DE-LA-PANDEMIA-POR-EL-COVID19.pdf

22. Sociedad Espanola de Cirugia oral y maxilofacial y de cabeza y cuello. Recomendaciones secomcyc en relacion con la cirugia y covid-19. http://facme.es/wp-content/uploads/2020/03/1.RECOMENDACIONES-GENERALES-SECOMCYC-ACTUA CION-COVID-19.pdf.

23. Quaranta N, Pantaleo A, Berrettini S, Cuda D, Murri A, Paludetti G, Galli J, Mincione A, Vicini A Piano strategico per la gestione del paziente orl durante il periodo di transizione a seguito della pandemia per il covid-19. https://www.sioechcf.it/piano-strat egico-per-la-gestione-del-paziente-orl-durante-il-periodo-di-trans izione-a-seguito-della-pandemia-covid-19/

24. Head and Neck Cancer Surgery at Department of Otorhinolaryngology, Srinagarind Hospital, Faculty of Medicine, Khon Kaen University, Thailand

25. University of Cape Town Division of Otolaryngology. COVID-19 Recommendations for the ENT Surgeon. https://www.globalchil drenssurgery.org/wp-content/uploads/2020/04/67-UCT_COVID19_Otolaryngology_ENTAfrica_Guidelines.pdf

26. Australian Society of Otolaryngology Head and Neck Surgery (2020) ASOHNS Review of Guidance for PPE for ENT surgeons during the COVID-19 Pandemic. https://umbraco.surgeons.org/ media/5189/asohns-updated-guidance-for-ppe-ent-surgeons-covid 19-2020-04-02.pdf 
27. Prunty S, Hinton-Bayre A (2020) Recommendations for PPE for Aerosol Generating Procedures during COVID-19 pandemic. http://www.asohns.org.au/CMS/Uploads/PPE\%20Recommen dations\%20COVID-19\%20ENT\%20WA\%20(3).pdf

28. Royal Australasian College of Surgeons. RACS guidelines for the management of surgical patients during the COVID-19 pandemic. http://anzast.org/wp-content/uploads/2020/03/racs-guidelines-forthe-management-of-surgical-patients-during-the-covid-19-pande mic.pdf

29. AGREE Next Steps Consortium (2017) The AGREE II Instrument (Electronic version). [http://www.agreetrust.org]. Accessed $1 \mathrm{Apr}$ 2020
30. Gabrysz-Forget F, Tabet P, Rahal A, Bissada E, Christopoulos A, Ayad T (2019) Free versus pedicled flaps for reconstruction of head and neck cancer defects: a systematic review. J Otolaryngol Head Neck Surg 48(1):13

Publisher's Note Springer Nature remains neutral with regard to jurisdictional claims in published maps and institutional affiliations. 